\title{
25. SEISMIC VELOCITIES OF LOWER CRUSTAL AND UPPER MANTLE ROCKS FROM THE SLOW- SPREADING MID-ATLANTIC RIDGE, SOUTH OF THE KANE TRANSFORM ZONE (MARK)
}

\author{
D. Jay Miller ${ }^{2}$ and Nikolas I. Christensen ${ }^{3}$
}

\begin{abstract}
Gabbroic rocks and peridotites are exposed on the seafloor on the western median valley wall of the Mid-Atlantic Ridge, south of the Kane Transform (MARK). The gabbroic rocks occupy an uplifted massif directly south of the transform-ridge intersection, whereas the peridotites extend $20 \mathrm{~km}$ along a median valley parallel ridge just south of the gabbro massif. Acoustic velocity measurements have been made at elevated confining pressures for a suite of samples extracted from drill cores collected during Ocean Drilling Program Leg 153. Drilling operations at Site 920 produced the deepest penetration and most substantial recovery to date in a coherent block of serpentinized peridotite from any ocean basin. Site 923 , in the gabbro massif, yielded nearly $75 \%$ recovery of fresh troctolite, olivine gabbro, and gabbro. A sample suite was selected from these drill cores to be representative of the primary lithologies recovered.

Evaluation of physical properties measurements from the serpentinized peridotites suggests that serpentinization is an ongoing and rapid process such that we can see evidence of changes in these properties over a time span of a few months and potentially as quickly as a few days. Samples showed a broad range of degree of serpentinization, even between samples only a few centimeters apart. A strong negative correlation exists between degree of serpentinization and density, as well as compressional- $\left(V_{p}\right)$ and shear- $\left(V_{s}\right)$ wave velocity, for samples from ophiolitic peridotites, and the serpentinized samples from MARK mimic this correlation. Published data indicate that $V_{p}, V_{s}$ and density of intensely serpentinized peridotites and fresh peridotites plot in separate and distinct fields as compared to values derived from gabbroic rocks. Physical properties data from moderately serpentinized peridotites from MARK, however, as well as published data from samples exhibiting partial serpentinization, are virtually indistinguishable from the values obtained from gabbroic rocks.

Physical properties data are in accord with petrographic observations, indicating that the gabbroic samples collected at MARK are considerably less altered than gabbroic rocks sampled from near Hess Deep. Data from gabbroic samples suggest that, given reliable densities, velocity data from remote geophysical surveys may be useful in estimating oceanic crustal modal composition. Elastic constants derived from physical properties measurements suggest that, although drilling in the gabbroic massif at MARK may be more difficult in terms of bit life than in other gabbroic exposures on the seafloor, the holes may well be more stable and conducive to extended drilling operations.
\end{abstract}

\section{INTRODUCTION}

Leg 153 of the Ocean Drilling Program (ODP) sailed to the MidAtlantic Ridge, south of the Kane Fracture Zone (MARK), as the second in a series of drilling programs with the objective of sampling the lower oceanic crust and upper mantle. Recognizing that drilling a complete section through the ocean crust is technologically challenging, the marine geoscience community and ODP have adopted a strategy of creating a composite section by drilling a succession of holes through tectonic windows where deep crustal and upper mantle rocks have been exhumed and emplaced at the seafloor. Lateral correlation of these sections is proposed to provide our best opportunity to constrain the interpretation of remote sensing seismic data until a continuous section through the oceanic crust is sampled intact.

Primarily from geophysical studies, the oceanic crust is thought to have a layered structure, with basaltic pillow lavas underlain by sheeted diabasic dikes, underlain in turn by a thick sequence (up to several kilometers) of gabbroic and ultramafic cumulates. This package overlies an upper mantle composed of peridotite, which has been chemically depleted by the extraction of partial melts (Moores and Vine, 1971; Casey et al., 1981). This interpretation is supported by investigations of obducted wedges of oceanic crust, ophiolites, that

'Karson, J.A., Cannat, M., Miller, D.J., and Elthon, D. (Eds.), 1997. Proc. ODP, Sci. Results, 153: College Station, TX (Ocean Drilling Program).

${ }^{2}$ Ocean Drilling Program, Texas A\&M University Research Park, 1000 Discovery Drive, College Station, TX, 77845, U.S.A. Jay_Miller@odp.tamu.edu

${ }^{3}$ Department of Earth and Atmospheric Sciences, Purdue University, West Lafayette, IN, 47907, U.S.A. are exposed on land (Coleman, 1977; Nicolas, 1989). What cannot currently be resolved by these investigations are the lateral and vertical continuity of these layers, particularly with respect to tectonic setting. Detailed mapping has heightened our awareness of the heterogeneity in lithologies exposed in the MARK area (Karson et al., 1987; Brown and Karson, 1988; Cannat et al., 1995), suggesting that a simple, layer-cake configuration is unlikely, particularly in areas with a low magma budget. Similarly, recent studies of other slowspreading environments indicate a thin and heterogeneous crustal structure (Fox and Stroup, 1981; Stroup and Fox, 1981; Karson et al., 1984; Karson and Fox, 1986; Cannat and Casey, 1995). Only by drilling a series of sections through the crust can we examine the continuity and lateral extent of these "layers" and investigate the nature of the transition from the crust to the mantle. This is of particular interest inasmuch as there remains an ongoing debate on the coincidence of the abrupt increase in seismic velocity and the transition from cumulate gabbroic rocks to residual mantle lithologies.

Submersible and dredging programs have demonstrated that gabbroic rocks outcrop in a large massif on the western wall of the MidAtlantic Ridge (MAR), just south of the Kane Transform (Fig. 1). The massif extends at least $15 \mathrm{~km}$ south of the Kane Transform, and is on the order of $8 \mathrm{~km}$ wide. These rocks are interpreted to be exposures of deep crustal rocks that have been exhumed by extensional tectonics at a slow-spreading mid-ocean ridge, with minimal magmatic activity (Karson and Dick, 1983; Karson et. al., 1987; Mével et al., 1991). This is in contrast to previous drilling programs that have sampled gabbroic rocks exposed by a propagating rift tip in fastspreading crust (ODP Leg 147, Hess Deep), and along an ultra-slowspreading ridge (ODP Leg 118, Southwest Indian Ridge). 
Figure 1. Generalized map of the MARK area, MidAtlantic Ridge at $22^{\circ} 35^{\prime}-23^{\circ} 40^{\prime} \mathrm{N}$ latitude. Site 920 lies on the serpentinite ridge, and Sites 921-924 are on the gabbro massif. Locations of previous ODP drill sites are also noted. Contours are in kilometers below sea level (after Detrick et al., [1988] and Cannat, Karson, Miller, et al., [1995]).

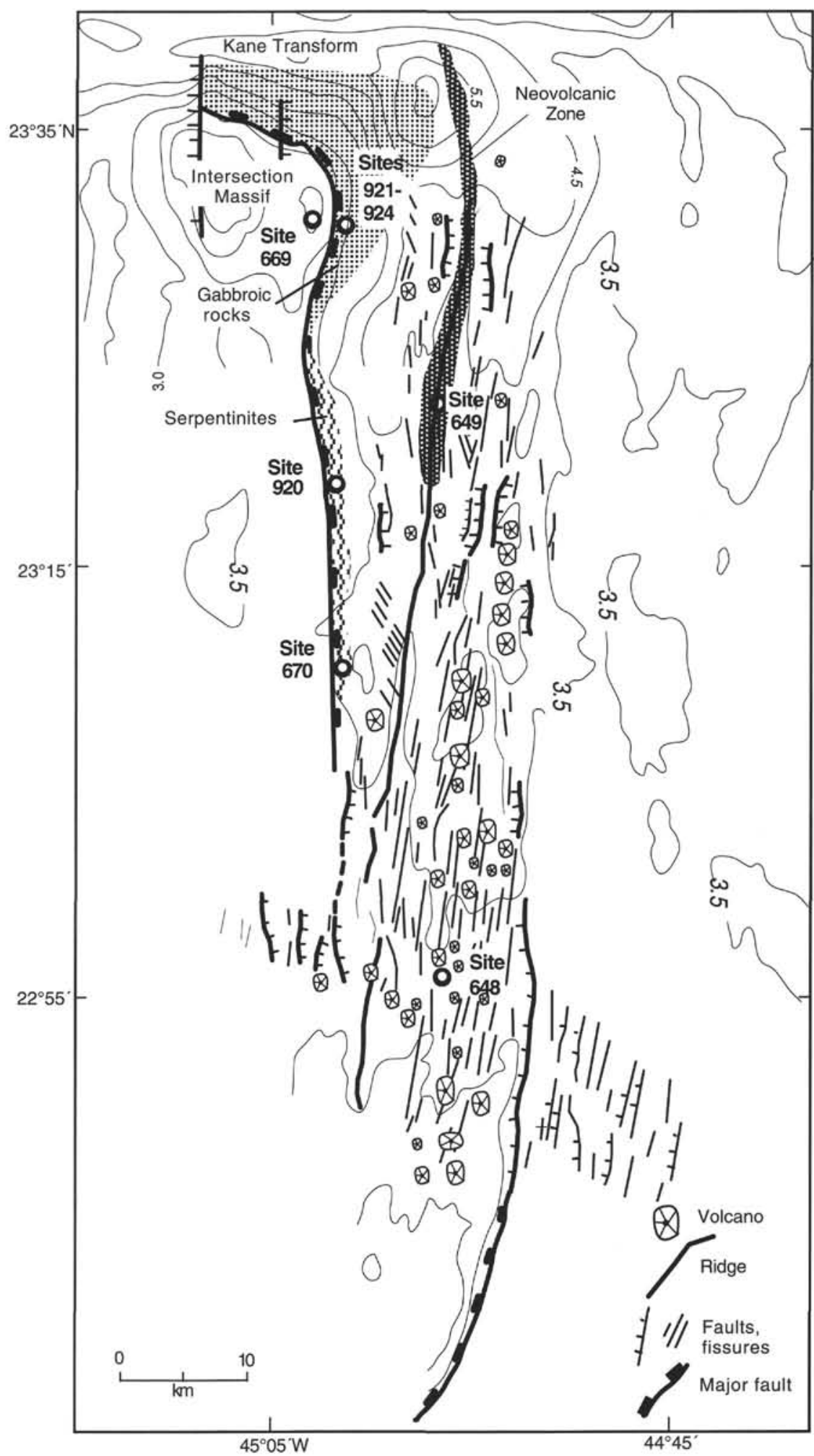

peridotite ridge (Cannat, M., Karson, J.A., Miller, D. J., et al., 1995) and this report documents the laboratory-measured seismic velocities of samples extracted from the recovered core.

Seismic velocities of these rocks are influenced by various parameters, including mineralogy, porosity, density, preferred mineral orientation, degree of alteration, and chemical composition. In this paper we examine velocity-porosity-density systematics and the potential contributions of mineralogy to seismic velocity. 


\section{EXPERIMENTAL METHODS}

Leg 153 drilled two deep holes in the peridotite ridge at Site 920, and from Hole 920D recovered more than $95 \mathrm{~m}$ of core with a penetration in excess of $200 \mathrm{~m}$. This represents the deepest penetration and most substantial volume of rock ever recovered from a coherent block of serpentinized peridotite in any of the world's ocean basins. In the gabbroic massif at Sites 921-924, multiple holes were drilled along a ridge-parallel and a ridge-perpendicular traverse with the objective of determining temporal and geometric heterogeneity. The sampling strategy for this study was specifically designed to characterize the primary lithologic units recovered. A total of 65 samples were examined during this research; 29 samples from the gabbroic section and 36 from the peridotite section. Locations of samples relative to recovery used in this study are presented in Figures 2 and 3.

Inasmuch as velocities at formation and emplacement pressures are different than velocities measured at atmospheric pressure (Birch, 1960), it is imperative that data used in examinations of crustal seismic velocity be obtained at appropriate elevated pressures. In the following section, the methods of sample preparation and density, porosity, and velocity measurements are described in detail.

The nominally 6.5 -cm-diameter core recovered during Leg 153 was bisected along its axis within a few minutes to hours after it was brought on deck. Minicores, used for shipboard physical properties measurement, oriented perpendicular to the cut face were usually extracted within a few hours after recovery. Near the end of the cruise, several drill-core axis-parallel minicores were taken as well to assess anisotropic properties. The minicore diameters were all $2.5 \mathrm{~cm}$, and lengths varied from 1.5 to $3.0 \mathrm{~cm}$. Both ends of the minicores were polished flat to within $0.2 \mathrm{~mm}$ to produce a right-circular cylinder, and polished thin sections were prepared from core end billets.

Compressional- $\left(V_{p}\right)$ and shear- $\left(V_{s}\right)$ wave velocities were measured at confining pressures up to $600 \mathrm{MPa}$ at the Purdue University Rock Physics Laboratory using the pulse transmission method (Christensen, 1965, 1985); results are compiled in Tables 1 and 2. Velocities were determined at room temperature to an accuracy of $1 \%$ from the traveltime of an elastic wave in a rock cylinder of known length using PZT and AC-cut quartz transducers with resonant frequencies of $1 \mathrm{MHz}$. The measurements were obtained by sending simultaneous electronic pulses to a transducer on the sample and a transducer inside a calibrated mercury delay line. During the measurement, waveforms from receiving transducers attached to the delay line and the sample are displayed on a dual-trace oscilloscope, and the length of the mercury delay line is adjusted such that the signals are superimposed, indicating that the pulse transmission time is the same for both the sample and the mercury column. Sample velocity $(v)$ is calculated from the measured sample length $(l)$, the length of the mercury column $\left(l_{\mathrm{Hg}}\right)$, and the velocity of mercury $\left(v_{\mathrm{Hg}}=1.446\right.$ $\mathrm{km} \mathrm{s}^{-1}$ at $30^{\circ} \mathrm{C}$; Christensen, 1985) according to the relationship

$$
v=l \times v_{\mathrm{Hg}} / l_{\mathrm{Hg}} .
$$

Confining pressure was measured by monitoring the change in resistivity of a manganin coil in contact with the pressure medium. Velocities were measured in incremental steps of increasing and decreasing pressure of $20 \mathrm{MPa}$ from ambient pressure to $100 \mathrm{MPa}$, and in steps of $50 \mathrm{MPa}$ from 100 to $600 \mathrm{MPa}$. All measurements were obtained at room temperature and samples were kept saturated in seawater. Examples of velocity change with respect to pressure change are shown in Figure 4. For all the samples examined in this study, velocity as a function of pressure increases linearly when the confining pressure exceeds $250-300 \mathrm{MPa}$, and it is nearly linear for most samples down to $200 \mathrm{MPa}$. Below $200 \mathrm{MPa}$, however, velocity rapidly decays as microcrack porosity attenuates elastic wave transmission. Because the samples examined in this research are interpreted to have been derived from the lower oceanic crust and upper mantle, we assume a minimum in situ confining pressure of $200 \mathrm{MPa}$ is applicable

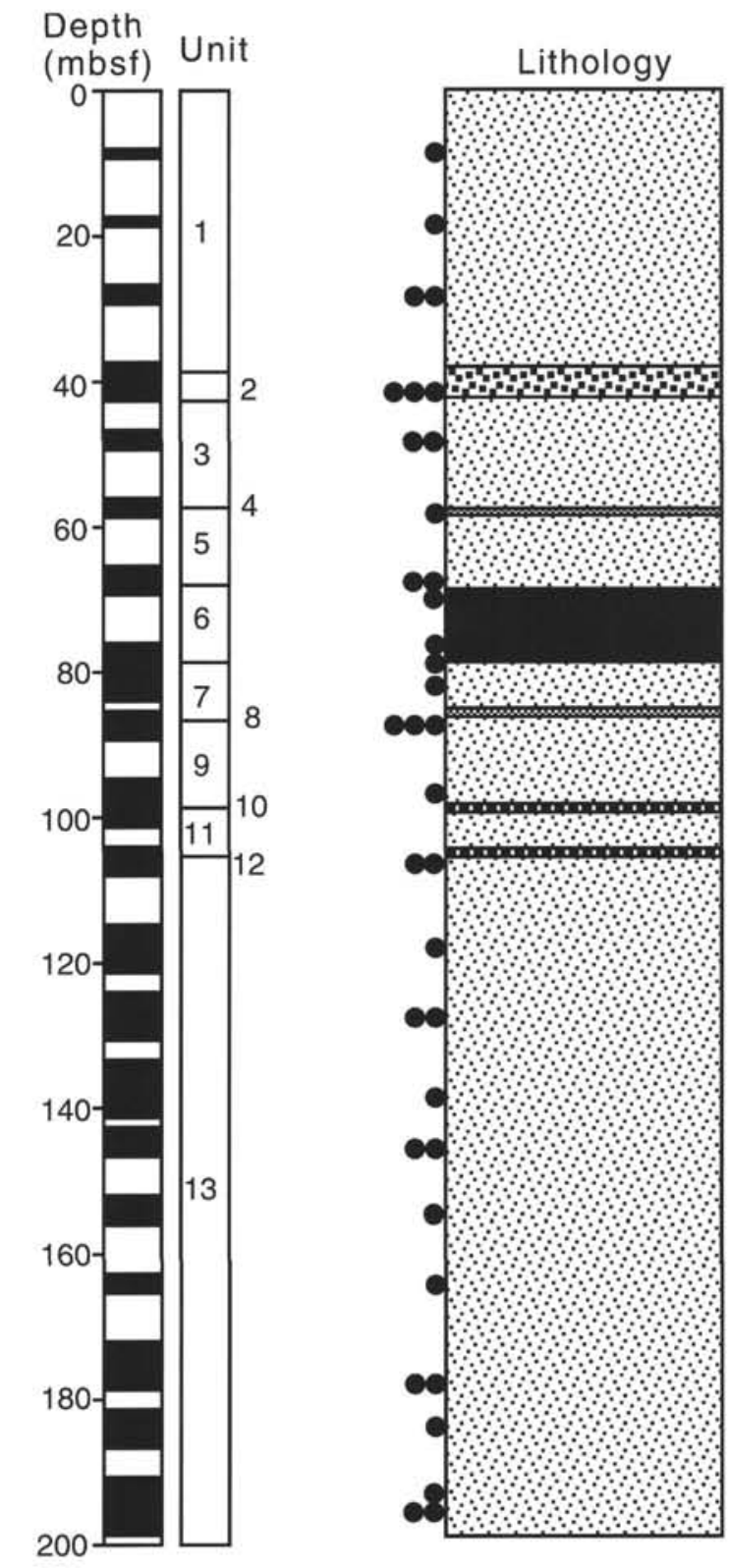

Serpentinized harzburgite

Pyroxene-rich serpentinized harzburgite

Metagabbro

Diabase

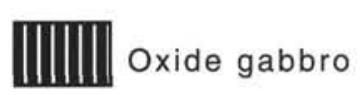

\section{- Sample location}

Figure 2. Schematic lithologic column for Site 920 . Recovery is indicated by black bars in left column. Units defined are based on pyroxene abundance in harzburgite and change in lithology. Relative depth of sample locations from Hole 920D are represented by solid circles. 


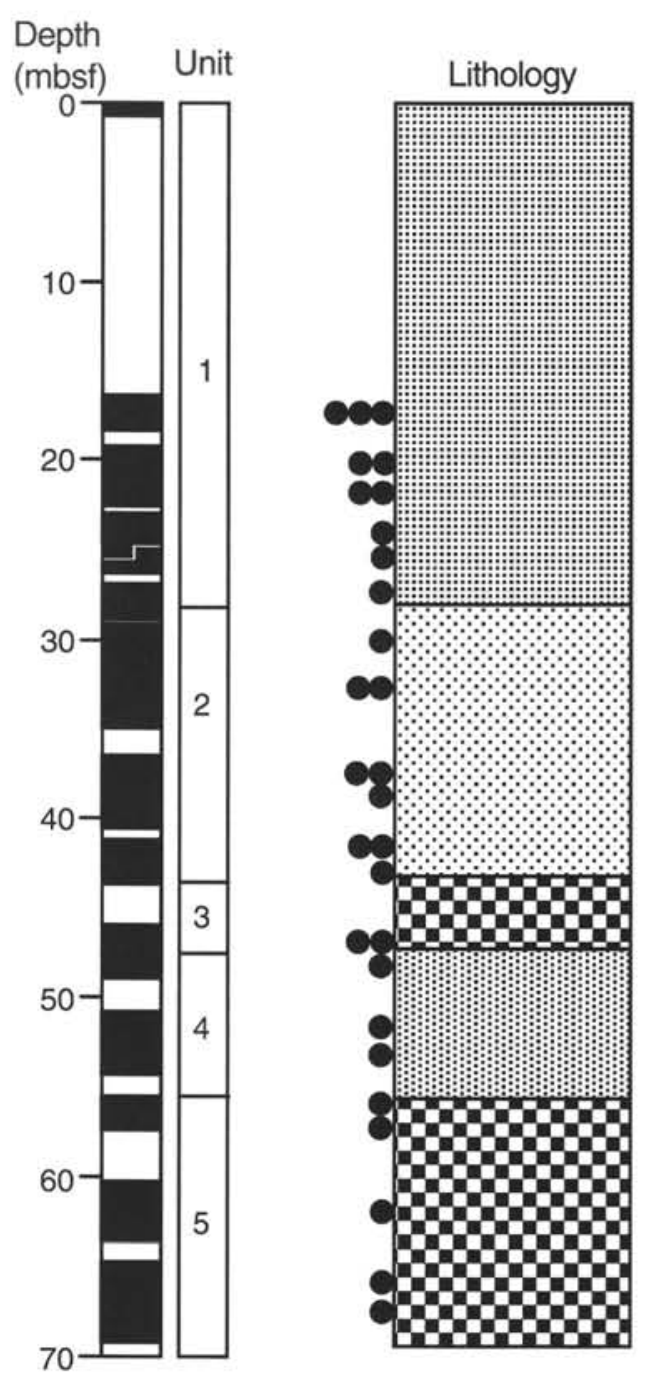

\section{Gabbro and olivine gabbro}

Troctolite and olivine gabbro

Poikilitic olivine gabbro and troctolite
Sample location

Figure 3. Schematic lithologic column for Site 923. Recovery is indicated by black bars in left column. Offset in recovery (left) column represents greater than $100 \%$ recovery in Core 923A-5R. Units defined are based on change in lithology. Relative depth of sample locations from Hole 923A are represented by solid circles.

to rocks presumed to be derived from the lower oceanic crust, and all results discussed hereafter are for that pressure. We recognize that reconstruction of the specific crustal depth associated with the rocks from the gabbro massif is a matter of some debate, and, if the gabbroic rocks are from the uppermost part of oceanic Layer 3, in situ pressure may be no more than $\sim 50 \mathrm{MPa}$. However, extrapolation of the $V_{p}$-pressure curves (e.g., Fig. 4) below $200 \mathrm{MPa}$ (which provides estimates of $V_{p}$ minimizing microcrack porosity control on velocity) exhibits a $\partial V_{p}$ of less than $0.1 \mathrm{~km} \mathrm{~s}^{-1}$ between 200 and $50 \mathrm{MPa}$.
Wet and dry sample weights were obtained on the ship using a motion-compensated microbalance for measuring mass $( \pm 0.002 \mathrm{~g} \mathrm{ac}-$ curacy). Sample volumes were determined on board by means of a pycnometer which used helium as the displacing fluid. Purge times of $5 \mathrm{~min}$ were used to approach a helium-saturated steady-state condition and to assure helium penetration into crevices and pore spaces with dimensions approaching one Angstrom $\left(10^{-10} \mathrm{~m}\right)$. Sample volumes were also determined from the diameters and lengths of the minicores. The two volume measurement methods agreed to within less than $1.5 \%$. After the wet sample weight was measured, the minicores were dried at $110^{\circ} \mathrm{C}$ for $24 \mathrm{hr}$ to drive off unbound water. After the dry sample weight was measured, the samples were resaturated with seawater before velocity measurements were made. Bulk density and porosity were calculated from the measurements described above.

Petrographic analyses were performed on polished thin sections, and descriptions are compiled in Tables 3 and 4. Modal analyses are based on visual estimation of component phases and point counts.

\section{RESULTS}

Gabbroic rocks from the intersection massif south of the Kane Fracture Zone sampled at Site 923 have a mean bulk density of 2.91 $\mathrm{g} \mathrm{cm}^{-3}$ and a standard deviation (s.d.) of $0.06 \mathrm{~g} \mathrm{~cm}^{-3}$. In comparison, the serpentinized peridotites sampled at Site 920 have a mean bulk density of $2.65 \mathrm{~g} \mathrm{~cm}^{-3}$ (s.d. $=0.09 \mathrm{~g} \mathrm{~cm}^{-3}$ ). Average porosity of the gabbroic rocks measured aboard ship was $1.23 \%$ (s.d. $=0.30 \%$ ), whereas porosity calculated from measurements made several months post-cruise is $1.31 \%$ (s.d. $=0.72 \%$ ). Average porosity in the peridotites measured aboard ship was $4.18 \%$ (s.d. $=2.08 \%$ ). Postcruise studies revealed that porosity in the peridotite samples was $1.32 \%$ (s.d. $=0.72 \%$ ). Mean compressional-wave velocity at 200 $\mathrm{MPa}$ for the gabbroic rocks is $7.01 \mathrm{~km} \mathrm{~s}^{-1}\left(\mathrm{~s} . \mathrm{d}=0.15 \mathrm{~km} \mathrm{~s}^{-1}\right)$. For the ultramafic rocks, mean $V_{p}$ at $200 \mathrm{MPa}$ is $5.42 \mathrm{~km} \mathrm{~s}^{-1}$ (s.d. $=0.39 \mathrm{~km}$ $\mathrm{s}^{-1}$ ). Mean shear-wave velocity for the gabbroic rocks is $3.84 \mathrm{~km} \mathrm{~s}^{-1}$ (s.d. $\left.=0.13 \mathrm{~km} \mathrm{~s}^{-1}\right)$. Mean $V_{s}$ for the peridotites is $2.61 \mathrm{~km} \mathrm{~s}^{-1}(\mathrm{~s} . \mathrm{d}$. $=$ $0.34 \mathrm{~km} \mathrm{~s}^{-1}$ ).

In the following discussion, the influences of porosity, density, mineralogy, and alteration on the seismic properties of rocks from Sites 920 and 923 are explored. Dynamic elastic constants are calculated from laboratory-measured velocities and densities, and the elastic behavior of oceanic lower crustal and upper mantle rocks is examined, particularly with future oceanic crustal drilling programs in mind.

\section{DISCUSSION}

\section{Porosity and Density}

The effect of microcrack porosity on the seismic velocities of oceanic gabbroic and ultramafic rocks has undergone recent scrutiny (Iturrino et al., 1991; Iturrino et al., 1996; Miller et al., 1996). Figure 5 shows the calculated density-porosity relationship for rocks collected on Leg 153. There is a distinct grouping of the two primary divisions of lithologic types evident in these data. There appears to be no systematic relationship between density and porosity for the gabbroic rocks from Site 923 . There does appear to be a sublinear trend in the majority of the data from Site 920 , suggesting that density in the serpentinized peridotites is relatively invariant up to $2.5 \%$ porosity. All but three of the peridotite samples (the three with the highest densities) are intensely serpentinized. If porosity had a significant effect on density in these samples, we would expect to see the data emulate the trends defined by the contours representing calculated density change in response to increasing porosity. As this is not the case, we surmise that there is a higher order control on sample density.

Certainly one of the most intriguing data sets derived from shipboard and shore-based density-porosity analysis is the change in po- 
Table 1. Compressional- and shear-wave velocity data for samples from Site $\mathbf{9 2 0 .}$

\begin{tabular}{|c|c|c|c|c|c|c|c|c|c|c|c|c|c|c|c|}
\hline \multirow[b]{2}{*}{$\begin{array}{r}\text { Core, section, } \\
\text { interval (cm) }\end{array}$} & \multirow[b]{2}{*}{$\begin{array}{l}\text { Depth } \\
\text { (mbsf) }\end{array}$} & \multirow[b]{2}{*}{$\begin{array}{l}\text { Density } \\
\left(\mathrm{g} \mathrm{cm}^{-3}\right)\end{array}$} & & & & & & & Velocit & $\mathrm{km} \mathrm{s}^{-1}$ ) & & & & & \\
\hline & & & & Mode & $\begin{array}{c}20 \\
\mathrm{MPa}\end{array}$ & $\begin{array}{c}40 \\
\mathrm{MPa}\end{array}$ & $\begin{array}{c}60 \\
\mathrm{MPa}\end{array}$ & $\begin{array}{c}80 \\
\mathrm{MPa}\end{array}$ & $\begin{array}{l}100 \\
\mathrm{MPa}\end{array}$ & $\begin{array}{l}200 \\
\mathrm{MPa}\end{array}$ & $\begin{array}{l}300 \\
\mathrm{MPa}\end{array}$ & $\begin{array}{l}400 \\
\mathrm{MPa}\end{array}$ & $\begin{array}{l}500 \\
\mathrm{MPa}\end{array}$ & $\begin{array}{l}600 \\
\mathrm{MPa}\end{array}$ & Lithology \\
\hline 153-920D- & & & & & & & & & & & & & & & \\
\hline $2 \mathrm{R}-1,116-119$ & 9.16 & 3.01 & 0.17 & $V_{p}$ & 6.521 & 6.595 & 6.635 & 6.662 & 6.683 & 6.749 & 6.793 & 6.827 & 6.856 & 6.880 & Serpentinized \\
\hline & & & & & 3.589 & 3.804 & 3.878 & 3.908 & 3.923 & 3.956 & 3.974 & 3.987 & 3.997 & 4.005 & harzburgite \\
\hline $3 \mathrm{R}-1,49-52$ & 17.99 & 2.61 & 0.52 & $v^{3}$ & 4.996 & 5.070 & 5.112 & 5.142 & 5.165 & 5.237 & 5.283 & 5.316 & 5.343 & 5.365 & Serpentinized \\
\hline & & & & & 2.445 & 2.522 & 2.563 & 2.586 & 2.599 & 2.623 & 2.633 & 2.640 & 2.645 & 2.649 & harzburgite \\
\hline $4 \mathrm{R}-3,35-38(\mathrm{H})$ & 30.19 & 2.64 & 0.66 & $V_{p}$ & 5.105 & 5.196 & 5.245 & 5.278 & 5.304 & 5.389 & 5.449 & 5.496 & 5.534 & 5.567 & Serpentinized \\
\hline & & & & & 2.465 & 2.543 & 2.582 & 2.602 & 2.612 & 2.629 & 2.635 & 2.639 & 2.642 & 2.644 & harzburgite \\
\hline $4 \mathrm{R}-3,38-41(\mathrm{~V})$ & 30.22 & 2.63 & 0.90 & & 5.175 & 5.240 & 5.274 & 5.299 & 5.321 & 5.405 & 5.466 & 5.512 & 5.548 & 5.578 & Serpentinized \\
\hline & & & & $\mathrm{rs}_{\mathrm{s}}$ & 2.546 & 2.602 & 2.630 & 2.643 & 2.651 & 2.662 & 2.666 & 2.669 & 2.671 & 2.673 & harzburgite \\
\hline $5 R-3,20-23$ & 39.47 & 2.61 & 0.41 & $V_{p}$ & 5.122 & 5.178 & 5.214 & 5.241 & 5.265 & 5.349 & 5.409 & 5.457 & 5.497 & 5.532 & Serpentinized \\
\hline & & & & & 2.355 & 2.409 & 2.438 & 2.455 & 2.465 & 2.481 & 2.487 & 2.490 & 2.493 & 2.495 & harzburgite \\
\hline $5 R-3,127-131$ & 40.54 & 2.56 & 1.97 & $V_{p}$ & 4.760 & 4.836 & 4.882 & 4.918 & 4.947 & 5.048 & 5.111 & 5.157 & 5.193 & 5.222 & Serpentinized \\
\hline & & & & $V_{s}$ & 2.422 & 2.439 & 2.450 & 2.456 & 2.461 & 2.473 & 2.479 & 2.482 & 2.485 & 2.487 & harzburgite \\
\hline $5 R-4,93-97$ & 41.66 & 2.61 & 1.79 & & 4.755 & 4.904 & 4.985 & 5.037 & 5.075 & 5.189 & 5.250 & 5.296 & 5.332 & 5.361 & Serpentinized \\
\hline & & & & & 2.223 & 2.262 & 2.285 & 2.300 & 2.310 & 2.330 & 2.336 & 2.341 & 2.344 & 2.346 & harzburgite \\
\hline $6 \mathrm{R}-1,53-56(\mathrm{H})$ & 47.03 & 2.58 & 1.17 & 1 & 4.628 & 4.785 & 4.870 & 4.929 & 4.974 & 5.112 & 5.195 & 5.255 & 5.302 & 5.340 & Serpentinized \\
\hline & & & & & 2.324 & 2.424 & 2.477 & 2.508 & 2.527 & 2.564 & 2.580 & 2.591 & 2.600 & 2.607 & harzburgite \\
\hline $6 \mathrm{R}-1,58-61(\mathrm{~V})$ & 47.08 & 2.61 & 1.58 & & 4.714 & 4.799 & 4.852 & 4.893 & 4.927 & 5.048 & 5.133 & 5.201 & 5.260 & 5.311 & Serpentinized \\
\hline & & & & & 2.232 & 2.351 & 2.410 & 2.440 & 2.458 & 2.492 & 2.508 & 2.519 & 2.528 & 2.535 & harzburgite \\
\hline $7 \mathrm{R}-1,124-128$ & 57.44 & 2.49 & 1.45 & $V_{p}$ & 4.706 & 4.867 & 4.957 & 5.012 & 5.049 & 5.135 & 5.178 & 5.208 & 5.231 & 5.250 & Serpentinized \\
\hline & & & & $V_{S}$ & 2.253 & 2.322 & 2.366 & 2.396 & 2.416 & 2.456 & 2.466 & 2.471 & 2.474 & 2.477 & harzburgite \\
\hline $8 \mathrm{R}-1,136-139(\mathrm{~V})$ & 67.29 & 2.61 & 1.16 & $V_{p}$ & 4.956 & 5.028 & 5.072 & 5.107 & 5.136 & 5.238 & 5.303 & 5.349 & 5.385 & 5.414 & Serpentinized \\
\hline & & & & & 2.351 & 2.406 & 2.433 & 2.447 & 2.454 & 2.466 & 2.470 & 2.473 & 2.476 & 2.477 & harzburgite \\
\hline $8 \mathrm{R}-1,141-144(\mathrm{H})$ & 67.31 & 2.61 & 0.76 & $V_{p}$ & 5.089 & 5.138 & 5.171 & 5.197 & 5.219 & 5.303 & 5.365 & 5.417 & 5.460 & 5.498 & Serpentinized \\
\hline & & & & & 2.447 & 2.479 & 2.497 & 2.508 & 2.516 & 2.538 & 2.549 & 2.558 & 2.564 & 2.569 & harzburgite \\
\hline $8 R-3,74-77$ & 69.54 & 2.70 & 1.26 & $V_{p}$ & 5.077 & 5.296 & 5.394 & 5.447 & 5.482 & 5.577 & 5.632 & 5.671 & 5.701 & 5.726 & Diabase \\
\hline & & & & $V_{\mathrm{s}}$ & 2.648 & 2.715 & 2.761 & 2.796 & 2.823 & 2.901 & 2.935 & 2.954 & 2.967 & 2.977 & \\
\hline $9 R-2,52-55$ & 77.37 & 2.77 & 0.59 & $V_{p}$ & 5.234 & 5.346 & 5.417 & 5.470 & 5.513 & 5.645 & 5.716 & 5.762 & 5.796 & 5.823 & Diabase \\
\hline & & & & & 2.840 & 2.878 & 2.905 & 2.926 & 2.943 & 2.996 & 3.024 & 3.041 & 3.052 & 3.060 & \\
\hline $10 \mathrm{R}-1,49-52(\mathrm{~V})$ & 78.59 & 2.75 & 1.88 & $V_{p}^{\prime}$ & 5.246 & 5.430 & 5.526 & 5.585 & 5.626 & 5.739 & 5.803 & 5.849 & 5.885 & 5.915 & Diabase \\
\hline $10 \mathrm{R}-1,54-57(\mathrm{H})$ & & & & $V_{s}$ & 2.601 & 2.625 & 2.640 & 2.653 & 2.664 & 2.703 & 2.732 & 2.754 & 2,772 & 2.789 & \\
\hline & 78.64 & 2.62 & 1.51 & $V_{n}$ & 4.716 & 4.823 & 4.881 & 5.197 & 5.219 & 5.303 & 5.365 & 5.417 & 5.460 & 5.498 & Diabase \\
\hline $10 \mathrm{R}-4,80-83$ & 83.24 & 2.68 & 0.16 & $\begin{array}{l}V_{s} \\
V_{s}\end{array}$ & $\begin{array}{l}2.643 \\
5.611\end{array}$ & 2.704 & 2.738 & 2.762 & 2.781 & 2.844 & 2.885 & 2.917 & 2.943 & 2.964 & \\
\hline & & & & $V_{p}$ & $\begin{array}{l}5.611 \\
2.839\end{array}$ & $\begin{array}{l}5.698 \\
2.902\end{array}$ & $\begin{array}{l}5.751 \\
2.938\end{array}$ & $\begin{array}{l}5.789 \\
2.960\end{array}$ & $\begin{array}{l}5.819 \\
2974\end{array}$ & $\begin{array}{l}5.906 \\
3.005\end{array}$ & $\begin{array}{l}5.954 \\
3.010\end{array}$ & $\begin{array}{l}5.988 \\
3.028\end{array}$ & $\begin{array}{l}6.014 \\
3.035\end{array}$ & $\begin{array}{l}6.035 \\
3.041\end{array}$ & Serpentinized \\
\hline $11 \mathrm{R}-1,27-30$ & 85.57 & 2.63 & 2.33 & $V_{p}^{s}$ & 4.633 & 4.710 & 4.756 & 4.792 & 4.823 & 4.928 & 4.995 & 5.043 & $\begin{array}{l}3.030 \\
5.080\end{array}$ & $\begin{array}{l}3.041 \\
5.111\end{array}$ & Serpentinized \\
\hline & & & & $V_{s}$ & 2.397 & 2.417 & 2.429 & 2.437 & 2.443 & 2.463 & 2.476 & 2.485 & 2.493 & 2.499 & harzburgite \\
\hline $11 \mathrm{R}-1,125-128(\mathrm{H})$ & 86.55 & 2.57 & 2.67 & $V_{p}$ & 4.423 & 4.503 & 4.556 & 4.598 & 4.634 & 4.767 & 4.865 & 4.946 & 5.015 & 5.075 & Serpentinized \\
\hline & & & & & 2.382 & 2.407 & 2.421 & 2.431 & 2.438 & 2.459 & 2.471 & 2.479 & 2.485 & 2.490 & harzburgite \\
\hline $11 \mathrm{R}-1,128-131(\mathrm{~V})$ & 86.58 & 2.61 & 1.09 & $V_{p}^{\prime}$ & 4.915 & 4.966 & 4.999 & 5.025 & 5.048 & 5.131 & 5.193 & 5.246 & 5.293 & 5.334 & Serpentinized \\
\hline & & & & $V$ & 2.425 & 2.467 & 2.485 & 2.494 & 2.498 & 2.504 & 2.506 & 2.507 & 2.508 & 2.509 & harzburgite \\
\hline $12 \mathrm{R}-1,104-108$ & 96.04 & 2.66 & 0.17 & $i_{p}$ & 5.614 & 5.693 & 5.742 & 5.777 & 5.804 & 5.880 & 5.918 & 5.945 & 5.965 & 5.981 & Serpentinized \\
\hline & & & & & 2.732 & 2.753 & 2.767 & 2.776 & 2.782 & 2.800 & 2.810 & 2.816 & 2.821 & 2.825 & harzburgite \\
\hline $13 \mathrm{R}-2,80-83(\mathrm{~V})$ & 106.29 & 2.67 & 1.84 & $V_{p}$ & 4.999 & 5.149 & 5.229 & 5.282 & 5.324 & 5.452 & 5.528 & 5.582 & 5.625 & 5.660 & Serpentinized \\
\hline & & & & $V_{s}$ & 2.360 & 2.550 & 2.620 & 2.650 & 2.664 & 2.694 & 2.710 & 2.721 & 2.730 & 2.737 & harzburgite \\
\hline $13 R-2,84-87(H)$ & 106.33 & 2.72 & 1.67 & $p$ & 5.089 & 5.226 & 5.302 & 5.355 & 5.395 & 5.521 & 5.596 & 5.650 & 5.692 & 5.727 & Serpentinized \\
\hline $14 R-4.137-140$ & & & & $V$ s & 2.562 & 2.611 & 2.638 & 2.656 & 2.668 & 2.704 & 2.724 & 2.738 & 2.749 & 2.758 & harzburgite \\
\hline & 119.86 & 2.61 & 1.72 & $V_{p}$ & 4.924 & 5.167 & 5.290 & 5.360 & 5.406 & 5.515 & 5.575 & 5.617 & 5.650 & 5.677 & Serpentinized \\
\hline $15 \mathrm{R}-2,92-95(\mathrm{H})$ & & & & & 2.165 & 2.193 & 2.210 & 2.221 & 2.230 & 2.252 & 2.263 & 2.270 & 2.276 & 2.280 & harzburgite \\
\hline & 126.04 & 2.63 & 2.08 & $V_{p}$ & 4.862 & 4.990 & 5.066 & 5.120 & 5.163 & 5.300 & 5.382 & 5.442 & 5.489 & 5.528 & Serpentinized \\
\hline $15 \mathrm{R}-2.95-98(\mathrm{~V})$ & & & & $V_{s}$ & 2.123 & 2.263 & 2.343 & 2.391 & 2.422 & 2,483 & 2.507 & 2.524 & 2.537 & 2.547 & harzburgite \\
\hline & 126.07 & 2.61 & 2.08 & $V_{p}$ & 4.791 & 4.868 & 4.918 & 4.957 & 4.989 & 5.111 & 5.200 & 5.274 & 5.337 & 5.392 & Serpentinized \\
\hline & & & & & 2.237 & 2,257 & 2.270 & 2.280 & 2.288 & 2.312 & 2.325 & 2.334 & 2.339 & 2.343 & harzburgite \\
\hline $16 \mathrm{R}-4,82-85$ & 137.80 & 2.54 & 1.66 & $V_{p}$ & 4.544 & 4.808 & 4.919 & 4.976 & 5.011 & 5.104 & 5.157 & 5.195 & 5.225 & 5.249 & Serpentinized \\
\hline & & & & $V_{s}$ & 1.993 & 2.022 & 2.041 & 2.056 & 2.066 & 2.096 & 2.110 & 2.118 & 2.124 & 2.128 & harzburgite \\
\hline $17 \mathrm{R}-3,2-5(\mathrm{H})$ & 145.39 & 2.57 & 2.18 & $V_{p}$ & 4.849 & 4.967 & 5.036 & 5.085 & 5.122 & 5.240 & 5.310 & 5.360 & 5.399 & 5.432 & Serpentinized \\
\hline & & & & & 2.368 & 2.401 & 2.421 & 2.434 & 2.444 & 2.470 & 2.483 & 2.492 & 2.499 & 2.505 & harzburgite \\
\hline $17 \mathrm{R}-3,5-8(\mathrm{~V})$ & 145.42 & 2.61 & 1.69 & $V_{p}$ & 4.841 & 4.918 & 4.966 & 5.003 & 5.034 & 5.144 & 5.221 & 5.284 & 5.338 & 5.385 & Serpentinized \\
\hline & & & & $V_{s}$ & 2.104 & 2.121 & 2.130 & 2.136 & 2.141 & 2.160 & 2.174 & 2.185 & 2.194 & 2.202 & harzburgite \\
\hline $18 \mathrm{R}-4,12-15$ & 156.85 & 2.63 & 0.47 & & 5.644 & 5.708 & 5.743 & 5.766 & 5.784 & 5.839 & 5.876 & 5.906 & 5.931 & 5.952 & Serpentinized \\
\hline & & & & & 2.581 & 2.595 & 2.604 & 2.611 & 2.615 & 2.628 & 2.635 & 2.640 & 2.644 & 2.647 & harzburgite \\
\hline $19 \mathrm{R}-1,18-21$ & 162.48 & 2.65 & 0.32 & $V_{p}$ & 5.306 & 5.454 & 5.522 & 5.561 & 5.587 & 5.660 & 5.703 & 5.733 & 5.757 & 5.777 & Serpentinized \\
\hline & & & & $V_{s}$ & 2.578 & 2.637 & 2.670 & 2.690 & 2.702 & 2.727 & 2.738 & 2.745 & 2.750 & 2.755 & harzburgite \\
\hline $20 R-5,95-99(V)$ & 177.95 & 2.66 & 1.93 & & 5.058 & 5.118 & 5.159 & 5.191 & 5.219 & 5.326 & 5.408 & 5.478 & 5.539 & 5.593 & Serpentinized \\
\hline & & & & & 2.475 & 2.517 & 2.540 & 2.555 & 2.566 & 2.599 & 2.620 & 2.638 & 2.653 & 2.666 & harzburgite \\
\hline $20 \mathrm{R}-5,98-101(\mathrm{H})$ & 177.98 & 2.62 & 2.25 & $V_{p}$ & 4.836 & 5.084 & 5.195 & 5.256 & 5.295 & 5.400 & 5.460 & 5.504 & 5.538 & 5.566 & Serpentinized \\
\hline & & & & $V_{x}^{P}$ & 2.194 & 2.220 & 2.235 & 2.246 & 2.254 & 2.280 & 2.296 & 2.309 & 2.318 & 2.326 & harzburgite \\
\hline $21 \mathrm{R}-2,97-100$ & 183.72 & 2.59 & 1.19 & & 4.794 & 4.969 & 5.082 & 5.163 & 5.222 & 5.369 & 5.431 & 5.469 & 5.498 & 5.522 & Serpentinized \\
\hline & & & & $V / s$ & 2.316 & 2.367 & 2.396 & 2.414 & 2.426 & 2.447 & 2.455 & 2.459 & 2.463 & 2.466 & harzburgite \\
\hline $22 \mathrm{R}-3,17-20$ & 192.90 & 2.82 & 0.25 & $V_{p}$ & 5.670 & 5.771 & 5.838 & 5.889 & 5.929 & 6.056 & 6.121 & 6.162 & 6.191 & 6.212 & Serpentinized \\
\hline & & & & $v_{s}$ & 3.022 & 3.073 & 3.103 & 3.124 & 3.139 & 3.180 & 3.201 & 3.215 & 3.227 & 3.236 & harzburgite \\
\hline $22 \mathrm{R}-4,42-45(\mathrm{~V})$ & 193.85 & 2.62 & 2.16 & $V_{p}$ & 4.555 & 4.677 & 4.753 & 4.811 & 4.860 & 5.024 & 5.126 & 5.199 & 5.257 & 5.305 & Serpentinized \\
\hline & & & & $3_{3}^{3}+2>0$ & 2.027 & 2.048 & 2.059 & 2.067 & 2.074 & 2.095 & 2.111 & 2.122 & 2.132 & 2.140 & harzburgite \\
\hline $22 \mathrm{R}-4,47-50(\mathrm{H})$ & 193.87 & 2.77 & 0.87 & $\overrightarrow{V_{p}}$ & 5.614 & 5.848 & 5.982 & 6.065 & 6.120 & 6.246 & 6.305 & 6.346 & 6.378 & 6.404 & Serpentinized \\
\hline & & & & $V_{s}^{\prime}$ & 2.801 & 2.910 & 2.974 & 3.015 & 3.041 & 3.087 & 3.100 & 3.108 & 3.115 & 3.120 & harzburgite \\
\hline
\end{tabular}

Notes: $(H)=$ horizontally oriented minicore (relative to core axis); $(V)=$ vertically oriented minicore.

rosity of the samples with time. Figure $6 \mathrm{~A}$ shows the change in porosity for gabbroic samples from within a few hours to 2 days after the cores were recovered, relative to a second measurement several months after the cruise. All of the samples from Site 923 exhibit either the same, or more commonly, slightly higher porosity values in the post-cruise analysis. Although the slight difference in porosity in these samples may be an artifact of interlaboratory analysis, the sys- tematic elevation of porosity with respect to time suggests a behavioral trend. A potential explanation for this phenomenon is that, as the cores relax, microcrack expansion caused by unloading leads to greater porosity.

In contrast, all of the serpentinized peridotite samples from Site 920 exhibit strikingly lower porosity values measured after the samples have been allowed to relax (Fig. 6B). We assume that micro- 
Table 2. Compressional- and shear-wave velocity data for samples from Site $\mathbf{9 2 3}$.

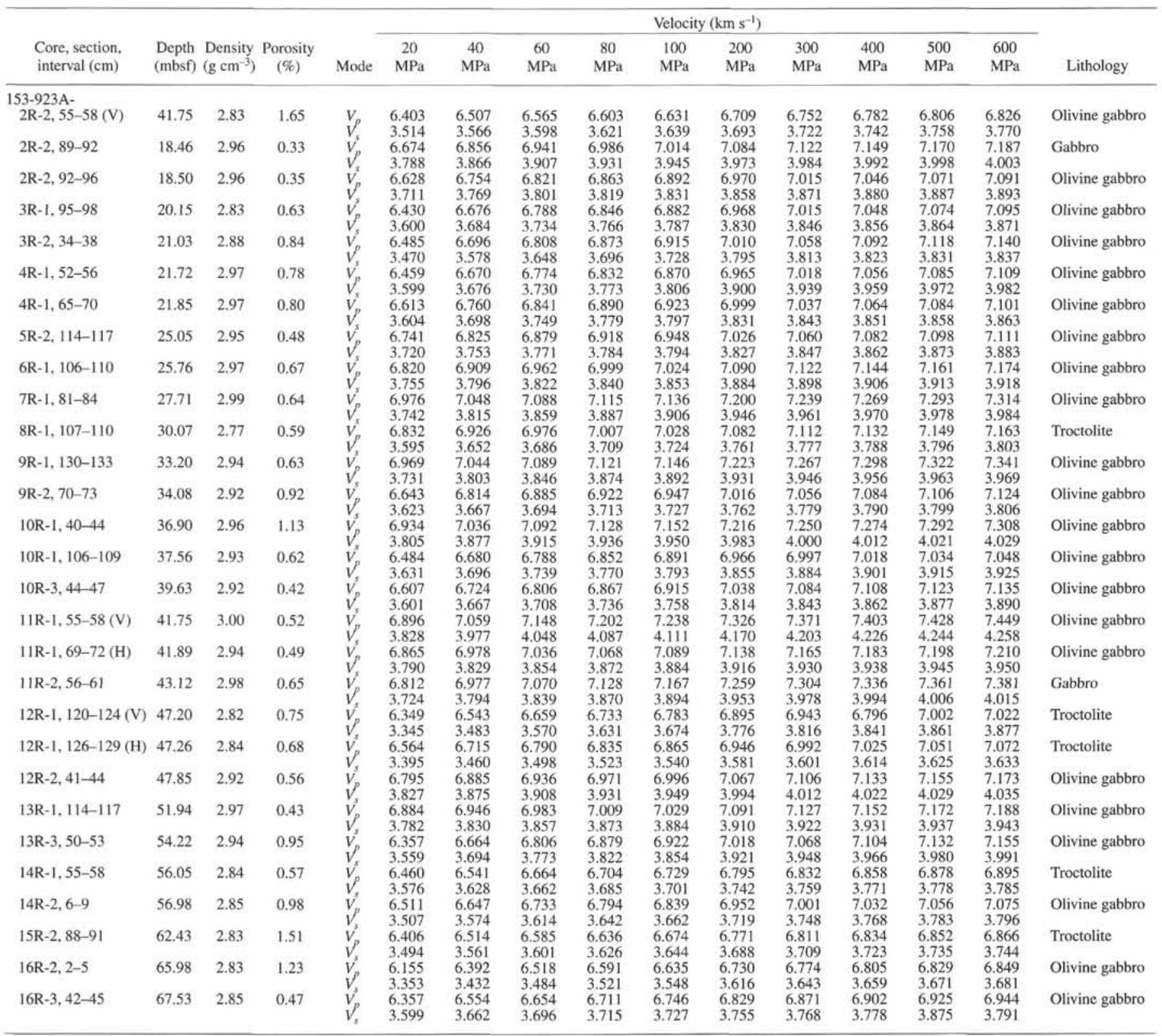

Notes: $(\mathrm{V})=$ vertically oriented minicore (relative to core axis); $(\mathrm{H})=$ horizontally oriented minicore.

crack propagation resulting from unloading is affecting these samples as well. If this is the case, then either serpentinization is an ongoing process, and volumetric expansion resulting from the serpentinization of olivine is filling the microcrack pore space as the sample ages, or latent volumetric expansion of serpentine contributes to the decrease in apparent porosity. The science party recognized that, within a few minutes to hours after splitting the core, serpentine veins had swelled, imparting relief to the originally smooth cut face. Inasmuch as these observations are so unique, experiments to test the kinetics of this behavior should be designed for the next time serpentinized peridotites are recovered by drilling.

Serpentinite swelling may have a significant impact on drilling operations. During Leg 153, drilling operations at Site 920 were suspended on several occasions when there appeared to be excess torque on the drill string monitored at the drill floor. Examination of the lower part of the drill string once the pipe was brought to the surface indicated the torque was not acting on the drill bit but on parts of the lower end of the drill string (several meters above the bit, but still be low the seafloor when the bit was operating) were seen to have been scored. Potentially, either pressure release by opening the hole allowed latent volumetric expansion of the serpentinized peridotite to close the sides of the hole, or ongoing serpentinization over the period of the drilling operation (a few days) caused the rock to swell and bind the drill string.

\section{Velocity and Density}

Birch $(1960,1961)$ presented the first detailed study of $V_{p}$ at elevated pressures in serpentinites. This study recognized that there was a proportional increase in compressional- wave velocity corresponding to an increase in density. Christensen (1966) expanded on this study, demonstrating that seismic anisotropy imparted by preferred mineral orientation contributed significantly to velocity behavior in partially serpentinized peridotites. Christensen (1966) also demon- 

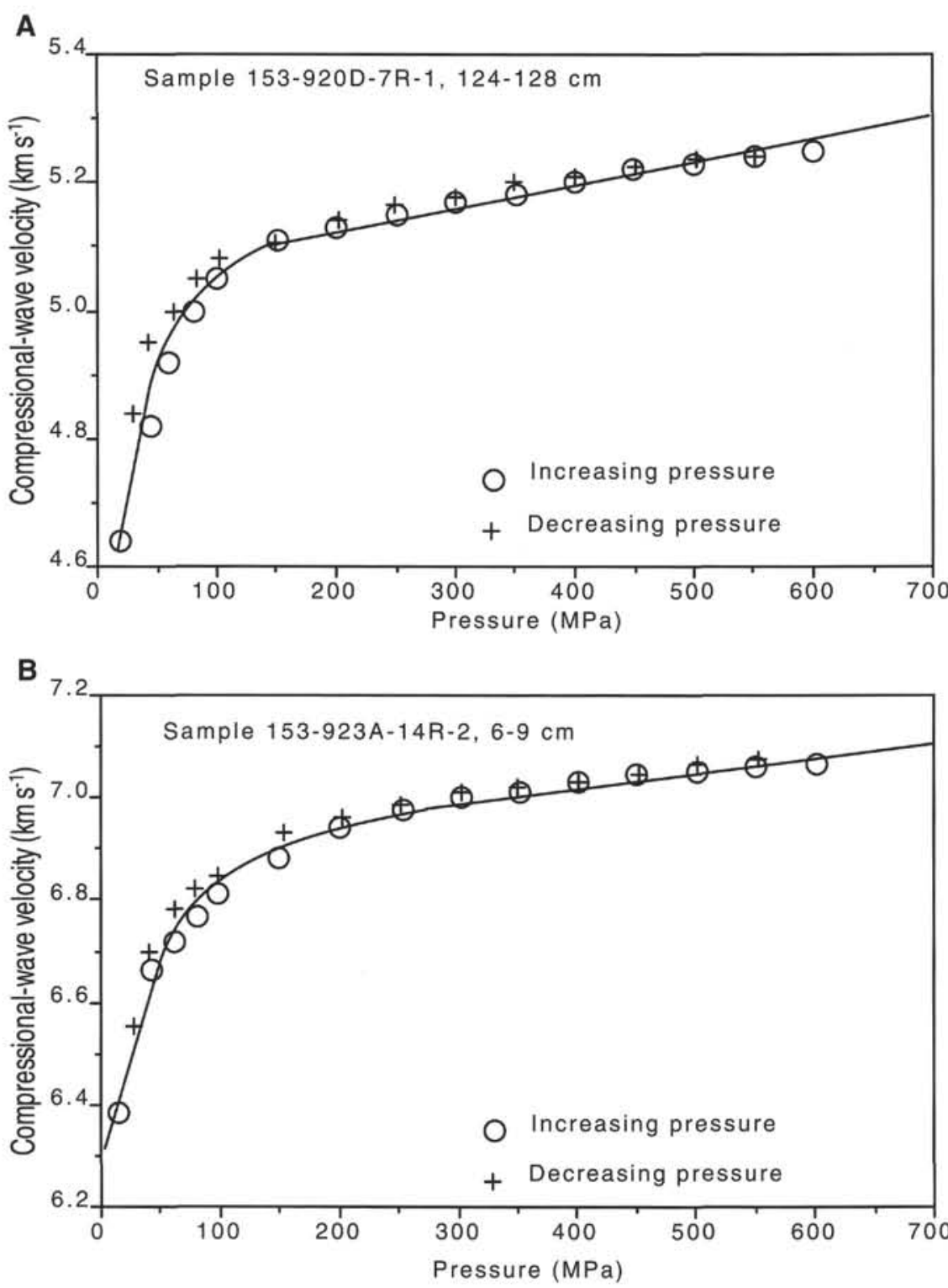

Figure 4. Effect of microcrack porosity on compressionalwave velocity as a function of increasing and decreasing pressure in (A) a serpentinized peridotite, and (B) a gabbroic rock. In both lithologic types the function is effectively linear above $200 \mathrm{MPa}$.

strated that serpentinite has a distinctly high Poisson's ratio relative to most other silicate rocks, theoretically allowing it to be distinguished from other rocks in geophysical studies of the oceanic crust.

A detailed evaluation of a continuous section of lower oceanic crustal gabbros was not possible until the late 1980s, when Leg 118 recovered a virtually complete $500-\mathrm{m}$ section of gabbroic crust from the Southwest Indian Ridge. Iturrino et al. (1991) demonstrated that these gabbroic rocks had very low porosities (most less than 1\%) and a high average $V_{p}\left(7.10 \mathrm{~km} \mathrm{~s}^{-1}\right)$. These data are precisely in accord with earlier studies that demonstrated that oceanic gabbroic rocks recovered by drilling, dredging and submersible programs had compressional-wave velocities in excess of $6.5 \mathrm{~km} \mathrm{~s}^{-1}$, consistent with oceanic seismic Layer 3 (Fox et al., 1973; Hyndman and Drury, 1976; Schreiber and Fox, 1977).

In a plot of $V_{p}$ vs. density, the lower crustal and upper mantle rocks from the MARK area fall in two well-defined clusters. The gabbroic rocks all have a relatively high $V_{p}$ and density, whereas the serpentinized peridotites are generally characterized by distinctly lower values (Fig. 7). The contours of constant mean atomic weight (MAW) in Figure 7 were calculated from Birch's Law (Birch, 1960, 1961) corrected to $200 \mathrm{MPa}$ according to the algorithm of Iturrino et al. (1991). The predicted MAW from velocity-density systematics shows the gabbroic rocks have a very limited range about an average of 21. This value is similar to that derived from fresh gabbroic rocks from the Southwest Indian Ridge (Iturrino et al., 1991). Similar lithologies from Hess Deep exhibited higher MAW values, because of abundant Fe-bearing hydrous phases (Iturrino et al., 1996), whereas the gabbroic rocks from MARK are virtually fresh. The serpentinized peridotites show a broader range of values, clustered about an average of 22 . This value is nearly identical to that reported for serpentinized peridotites at Hess Deep (Iturrino et al., 1996; Miller et al., 1996).

Expanding on the work of Birch $(1960,1961)$ and Christensen $(1966,1972,1978)$ regarding velocity behavior in serpentinized peridotites, we have drawn from the literature laboratory-measured velocity and degree of serpentinization data, which are presented in Figures 8 and 9. Although minor antigorite has been reported in oceanic serpentinized peridotites (Phillips et. al., 1969), lizardite/chrysotile is the far more abundant serpentine mineral. Because the high velocity associated with samples containing abundant antigorite (Christensen, 1978) can substantially skew the data, we have eliminated from our data set samples that were recognized to contain substantial amounts of antigorite. Least-squares analysis of the compiled data demonstrates that there is a distinct correlation between the fraction of the 
Table 3. Petrographic descriptions of samples from Hole 920D.

\begin{tabular}{|c|c|}
\hline top $(\mathrm{cm})$ & Description \\
\hline & Serpentinized peridotite. Remarkably fresh. $35 \%$ serpentine, $5 \%$ orthopyroxene, $60 \%$ olivine, trace chromite and clinopyroxene. Porphyroclastic texture. \\
\hline $3 \mathrm{R}-1,49$ & Serpentinized peridotite. $81 \%$ serpentine, $7 \%$ olivine, $5 \%$ orthopyroxene, $4 \%$ clinopyroxene, $3 \%$ magnetite, trace chromite. Foliation is poorly developed, but present. \\
\hline $4 \mathrm{R}-3,35$ & $\begin{array}{l}\text { Serpentinized peridotite. } 78 \% \text { serpentine, } 10 \% \text { orthopyroxene, } 7 \% \text { olivine, } 4 \% \text { magnetite, trace chromite. Slightly less serpentinized than Sample } 153-920 \mathrm{D}-3 \mathrm{R}-1,49 \\
\mathrm{~cm} \text {, a few more relic olivine kernels and fresher orthopyroxene, although foliation is somewhat stronger. Thin section of paired Sample } 153-920 \mathrm{D}-4 \mathrm{R}-3,38 \mathrm{~cm} \text {, has } \\
\text { slightly fewer fresh olivine kernels evident. } 80 \% \text { serpentinized. }\end{array}$ \\
\hline $5 \mathrm{R}-3,20$ & $\begin{array}{l}\text { Serpentinized peridotite. } 81 \% \text { serpentine, } 10 \% \text { orthopyroxene, } 5 \% \text { olivine, } 3 \% \text { magnetite, } 1 \% \text { chromite. Foliation is poorly developed. Well-developed mesh texture } \\
\text { in serpentine. }\end{array}$ \\
\hline $5 \mathrm{R}-3,127$ & Serpentinized peridotite. $92 \%$ serpentine, $3 \%$ orthopyroxene, $1 \%$ olivine, $3 \%$ magnetite, trace chromite. \\
\hline $5 R-4,93$ & Serpentinized peridotite. $86 \%$ serpentine, $7 \%$ orthopyroxene, $3 \%$ olivine, $3 \%$ magnetite, chromite. Well-developed mesh texture in serpentine. \\
\hline $6 \mathrm{R}-1,53$ & $\begin{array}{l}\text { Serpentinized peridotite. } 87 \% \text { serpentine, } 7 \% \text { orthopyroxene, } 3 \% \text { olivine, } 3 \% \text { magnetite, trace chromite. Thin section of paired Sample } 153-920 \mathrm{D}-6 \mathrm{R}-1,58 \mathrm{~cm} \text {, is } \\
\text { somewhat fresher, with a few more clots of relic olivine kernels. } 85 \% \text { serpentinized. }\end{array}$ \\
\hline $7 R-1,124$ & Serpentinized peridotite. Virtually entirely serpentinized $(98 \%)$, only a couple of fragments of relic orthopyroxene. Multiple crosscutting veins filled with serpentine. \\
\hline $8 \mathrm{R}-\mathrm{I}, 136$ & $\begin{array}{l}\text { Serpentinized peridotite. } 84 \% \text { serpentine, } 10 \% \text { orthopyroxene (in } 3 \text { large porphyroclasts), } 2 \% \text { olivine (in pressure shadows next to orthopyroxene), } 3 \% \text { magnetite, } 1 \% \\
\text { chromite (in small clusters). Well-developed foliation and mesh texture. Paired Sample } 153-920 \mathrm{D}-8 \mathrm{R}-1,141 \mathrm{~cm} \text {, has slightly less serpentine ( } 82 \% \text { ). }\end{array}$ \\
\hline $10 \mathrm{R}-4,80$ & $\begin{array}{l}\text { Serpentinized peridotite. Significantly fresher than most other samples. } 72 \% \text { serpentine, } 15 \% \text { olivine (in clusters of relic kernels), } 7 \% \text { orthopyroxene (half as much } \\
\text { fresh orthopyroxene as olivine), } 4 \% \text { chromite (in several clusters), } 2 \% \text { magnetite. Although fresh kernels of olivine are present, several serpentine veins cut the } \\
\text { sample. }\end{array}$ \\
\hline $11 \mathrm{R}-1.27$ & Serpentinized peridotite. $85 \%$ serpentine, $10 \%$ orthopyroxene, $3 \%$ olivine, $2 \%$ magnetite, trace chromite. Well-developed anastomosing foliation is present. \\
\hline $11 \mathrm{R}-1,125$ & $\begin{array}{l}\text { Serpentinized peridotite. } 93 \% \text { serpentine, } 5 \% \text { orthopyroxene, } 3 \% \text { magnetite. No fresh olivine kernels present. Paired Sample 153-920D-11R-1, } 128 \text { C } \\
\text { significantly more orthopyroxene }(10 \%) \text { and some relic olivine kernels }(5 \%) .83 \% \text { serpentinized. }\end{array}$ \\
\hline & Serpentinized peridotite. $74 \%$ serpentine, $15 \%$ orthopyroxene, $10 \%$ olivine, $1 \%$ magnetite. Poorly developed foliation. \\
\hline $13 \mathrm{R}$ & $\begin{array}{l}\text { Serpentinized peridotite. } 79 \% \text { serpentine, } 10 \% \text { orthopyroxene, } 5 \% \text { olivine, } 3 \% \text { clinopyroxene, } 2 \% \text { magnetite, } 1 \% \text { chromite (in small clusters). Well-developed } \\
\text { foliation. Clinopyroxene may be secondary, it has a wavy appearance. Paired sample } 153-920 \mathrm{D}-13 \mathrm{R}-2,84 \mathrm{~cm} \text {, appears to have roughly equal proportions of olivine } \\
\text { and orthopyroxene ( } 10 \% \text { each). } 74 \% \text { serpentinized. }\end{array}$ \\
\hline $14 \mathrm{R}$ - & Serpentinized peridotite. $85 \%$ serpentine, $6 \%$ orthopyroxene, $6 \%$ olivine, $2 \%$ magnetite, $1 \%$ chromite. Mesh texture well developed, but foliation is poorly developed. \\
\hline $15 \mathrm{R}-2,92$ & $\begin{array}{l}\text { Serpentinized peridotite. } 84 \% \text { serpentine, } 10 \% \text { orthopyroxene, } 3 \% \text { olivine (rare relic kernels in pressure shadows next to orthopyroxene porphyroclasts), } 3 \% \\
\text { magnetite. Wavy anastomosing foliation highlighted by relatively abundant magnetite stringers. Paired Sample } 153-920 \mathrm{D}-15 \mathrm{R}-2,95, \mathrm{~cm} \text { contains no relic olivine } \\
\text { kermels ( } 87 \% \text { serpentinized). }\end{array}$ \\
\hline $16 \mathrm{R}-4,82$ & $\begin{array}{l}\text { Serpentinized peridotite. } 93 \% \text { serpentine, virtually no olivine left, } 5 \% \text { orthopyroxene (in a couple of porphyroclasts), } 2 \% \text { magnetite. Well-developed anastomosing } \\
\text { foliation bends around porphyroclasts. }\end{array}$ \\
\hline $17 \mathrm{R}-3,2$ & $\begin{array}{l}\text { Serpentinized peridotite. } 92 \% \text { serpentine, no fresh olivine, large porphyroclasts of orthopyroxene, slightly more abundant than in Sample } 16 \mathrm{R}-4,82 \mathrm{~cm}(6 \%), 2 \% \\
\text { magnetite. Paired Sample } 153-920 \mathrm{D}-17 \mathrm{R}-3,5 \mathrm{~cm} \text {, contains even more orthopyroxene (10\%) and a few kernels of relic olivine }(2 \%) .85 \% \text { serpentine. }\end{array}$ \\
\hline $18 \mathrm{R}-4,12$ & $\begin{array}{l}\text { Serpentinized peridotite. } 79 \% \text { serpentine, } 15 \% \text { orthopyroxene, } 5 \% \text { olivine, } 1 \% \text { magnetite, trace chromite. Strong anastomosing foliation, wraps around orthopyroxene } \\
\text { porphyroclasts. Olivine is always as relic kernels near orthopyroxene. }\end{array}$ \\
\hline $19 \mathrm{R}-1,18$ & $\begin{array}{l}\text { Serpentinized peridotite. } 76 \% \text { serpentine, } 15 \% \text { orthopyroxene, } 5 \% \text { olivine } 3 \% \text { magnetite, } 1 \% \text { chromite. Dense mesh of magnetite stringers without a well-developed } \\
\text { foliation. }\end{array}$ \\
\hline $20 \mathrm{R}-5,95$ & $\begin{array}{l}\text { Serpentinized peridotite. } 80 \% \text { serpentine } 10 \% \text { olivine, } 8 \% \text { orthopyroxene } 1 \% \text { magnetite, } 1 \% \text { chromite (in small clusters). Mesh texture well developed in serpentine, } \\
\text { no strong foliation. Rare large olivine kernel clusters. Paired Sample } 153-920 \mathrm{D}-20 \mathrm{R}-5,98 \mathrm{~cm} \text {, has less olivine }(5 \%) \text { and orthopyroxene }(5 \%) \text { with more magnetite } \\
(2 \%) \text { and chromite }(2 \%), 86 \% \text { serpentine. }\end{array}$ \\
\hline $21 \mathrm{R}-2,97$ & $\begin{array}{l}\text { Serpentinized peridotite. Looks very similar to Sample } 153-920 \mathrm{D}-20 \mathrm{R}-5,98 \mathrm{~cm} .86 \% \text { serpentine, } 5 \% \text { each olivine and orthopyroxene and less, but roughly equal, } \\
\text { amounts of magnetite and chromite. Chromite occurs in an trail of small grains, roughly parallel to overall foliation. }\end{array}$ \\
\hline $22 \mathrm{R}-3,17$ & $\begin{array}{l}\text { Serpentinized peridotite. Quite fresh, with abundant orthopyroxene ( } 20 \%) \text {, fresh clinopyroxene (10\%), relic olivine kernels } 10 \%, 2 \% \text { magnetite, } 1 \% \text { chromite. } 57 \% \\
\text { serpentine. No distinct foliation orientation. }\end{array}$ \\
\hline $22 \mathrm{R}-4,42$ & $\begin{array}{l}\text { Serpentinized peridotite. This sample and its pair look radically different. Sample } 153-920 \mathrm{D}-22 \mathrm{R}-4,42 \mathrm{~cm} \text {, is } 86 \% \text { serpentine, with pervasively altered orthopyroxene } \\
10 \% \text { and virtually no fresh olivine (rare kernels: } 1 \%-2 \% \text { ), } 2 \% \text { magnetite. This sample is pervasively serpentinized, paired core (Sample } 153-920 \mathrm{D}-22 \mathrm{R}-4,47 \mathrm{~cm}) \text { is } \\
\text { much fresher. It contains } 20 \% \text { orthopyroxene that is less altered, } 10 \% \text { olivine and a small amount of clinopyroxene } 5 \% \text {. This sample is only } 64 \% \text { serpentine and } 1 \% \\
\text { magnetite. Texturally, however, the samples are very similar with a distinct preferred elongation direction of porphyroclasts that mimics a distinct foliation } \\
\text { direction. }\end{array}$ \\
\hline
\end{tabular}

rock which has been serpentinized and density (Fig. 8). When density-serpentinization data from Hess Deep serpentinized peridotites and the peridotites from the MARK area are included in the data set, there is virtually no change in the correlation coefficient $\left(R^{2}=0.976\right)$, suggesting that this relation is valid for serpentinized peridotites exposed at both fast- and slow-spreading ridges. Studies from several ophiolite complexes have reported a similar correlation (Ramana and Rao, 1974; Aslanyan et al., 1976, Kern and Tubia, 1993). As illustrated in Figure 9, there is a similar distinct correlation between the degree of serpentinization and both $V_{p}\left(\mathrm{R}^{2}=0.95\right)$ and $V_{s}\left(\mathrm{R}^{2}=0.93\right)$. These data may allow interpretation of the fraction of the suboceanic mantle that has undergone serpentinization when $V_{p}$ and $V_{s}$ can be determined by remote seismic methods.

\section{Velocity and Mineralogy}

Whereas the individual minerals present in undeformed oceanic rocks are commonly seismically anisotropic (i.e., $\mathrm{An}_{56}$ plagioclase can have a $V_{p}$ ranging from $7.33 \mathrm{~km} \mathrm{~s}^{-1}$ to $6.64 \mathrm{~km} \mathrm{~s}^{-1}$ depending on propagation direction relative to the crystallographic axis [Christensen, 1982]), and seismic velocity can vary within zoned minerals, the rocks tend to behave isotropically or nearly so because of random orientation of the crystallographic axes of the constituent phases. Limits for the velocities of mineral aggregates have been calculated from elastic constants assuming uniform stress and strain (Voigt, 1928; Reuss, 1929). The mean of the velocities, the Voigt-Reuss-Hill averages (VRH, after Hill, 1952), can be used as an estimate of the velocity of a monomineralic rock. Assuming the samples from MARK have a random grain orientation, velocity-density data from MARK area samples should fall within a polygonal field where the apices are the VRH averages of the principal minerals present.

Figure 10 shows a plot in velocity-density space, with the VRH averages of plagioclase, hornblende, augite, and olivine forming the apices of a polygon that encompasses virtually all the data from Site 923. The single sample falling near the olivine plagioclase join is a bimineralic, plagioclase-rich troctolite (see Table 3 ). The three samples along the plagioclase-hornblende join represent the three most altered gabbroic rocks examined. Data from all other samples fall within the triangle defined by augite, olivine, and plagioclase VRH averages, and the general proportions of phases $(50 \%-75 \%$ plagioclase, clinopyroxene abundance $>$ olivine abundance, agree well with modal analyses (see Table 3 ).

A similar VRH-type plot for data from the serpentinized peridotites of Site 920 (Fig. 11) shows that most of the data clusters near the serpentine apex. Inasmuch as no VRH data exist for serpentine, we have used average $V_{p}$ and density data for serpentine compiled by Christensen $(1966,1972,1978)$ Once again we note in this diagram the correlation between increasing degree of serpentinization and de- 
Table 4. Petrographic descriptions of samples from Hole 923A.

\begin{tabular}{|c|c|}
\hline $\begin{array}{l}\text { Core, section, } \\
\text { top }(\mathrm{cm})\end{array}$ & Description \\
\hline $\begin{array}{l}53-923 \mathrm{~A}- \\
2 \mathrm{R}-2,2\end{array}$ & $\begin{array}{l}\text { Olivine gabbro. } 70 \% \text { plagioclase, } 15 \% \text { clinopyroxene, } 5 \% \text { olivine, } 5 \% \text { amphibole alteration after clinopyroxene. Clinopyroxene grains are as large as } 6 \mathrm{~mm} \text { as is } \\
\text { plagioclase. Olivine grains are all less than } 5 \mathrm{~mm} \text { across. Cumulate textured. Medium grained. }\end{array}$ \\
\hline $2 \mathrm{R}-2,92$ & $\begin{array}{l}\text { Gabbro. } 55 \% \text { plagioclase, } 37 \% \text { clinopyroxene, } 3 \% \text { orthopyroxene, } 2 \% \text { titanoilmenite, } 1 \% \text { olivine. Pervasively recrystallized, but minerals are all very fresh in } \\
\text { appearance. Oxides occur in a } 2 \text {-mm-wide band. Three grain-size populations. Coarsest appears to be igneous textured, intermediate and finer grained } \\
\text { populations appear recrystallized. }\end{array}$ \\
\hline $3 \mathrm{R}-1,95$ & $\begin{array}{l}\text { Olivine gabbro. } 75 \% \text { plagioclase, } 15 \% \text { clinopyroxene, } 5 \% \text { olivine, trace orthopyroxene. Weakly recrystallized plagioclase. Pyroxene does not appear to be } \\
\text { recrystallized. } 2 \% \text { total alteration. Medium grained. }\end{array}$ \\
\hline $3 R-2,34$ & $\begin{array}{l}\text { Olivine gabbro. } 54 \% \text { plagioclase. } 35 \% \text { clinopyroxene, } 11 \% \text { olivine, trace orthopyroxene and titanoilmenite. Sample has undergone solid-state deformation, but } \\
\text { little or no alteration minerals are present (less than } 1 \% \text { ). Medium to fine grained (finer grained minerals are recrystallized). }\end{array}$ \\
\hline $4 \mathrm{R}-1,52$ & $\begin{array}{l}\text { Olivine gabbro. Paired core (Sample } 153-923 \mathrm{~A}-4 \mathrm{R}-1.65 \mathrm{~cm} \text { ) is identical in appearance. } 50 \% \text { plagioclase, } 25 \% \text { olivine, } 19 \% \text { clinopyroxene, } 2 \% \text { orthopyroxene, } 1 \% \\
\text { titanoilmenite, } 2 \% \text { amphibole after clinopyroxene. Nearly coarse-grained rock. Olivine is strained. Plagioclase is recrystallized into fine, equant grains. }\end{array}$ \\
\hline $5 R-2,114$ & $\begin{array}{l}\text { Olivine gabbro. } 65 \% \text { plagioclase, } 22 \% \text { clinopyroxene, } 9 \% \text { olivine, } 2 \% \text { orthopyroxene, trace titanoilmenite, } 1 \% \text { amphibole after clinopyroxene. Very fresh, } \\
\text { plagioclase-rich rock. Medium grained, adcumulate textured. }\end{array}$ \\
\hline $6 \mathrm{R}-1,106$ & $\begin{array}{l}\text { Olivine gabbro. } 55 \% \text { plagioclase, } 34 \% \text { clinopyroxene, } 9 \% \text { olivine, trace of titanoilmenite, } 1 \% \text { amphibole after clinopyroxene. Predominantly cumulate-textured, } \\
\text { medium-grained rock. Plagioclase shows minor recrystallization to finer, equant grains. }\end{array}$ \\
\hline $7 \mathrm{R}-1,81$ & $\begin{array}{l}\text { Olivine gabbro. } 60 \% \text { plagioclase, } 29 \% \text { clinopyroxene, } 9 \% \text { olivine, trace titanoilmenite, } 1 \% \text { amphibole after clinopyroxene. Coarse grained, cumulate textured. } \\
\text { Some finer grained plagioclase is present as well. }\end{array}$ \\
\hline $8 \mathrm{R}-1,107$ & Troctolite. $75 \%$ plagioclase, $18 \%$ olivine, $4 \%$ clinopyroxene, trace titanoilmenite, $1 \%$ amphibole. Well-preserved adcumulate texture. Medium grained. \\
\hline $9 \mathrm{R}-1,130$ & $\begin{array}{l}\text { Olivine gabbro. } 53 \% \text { plagioclase, } 33 \% \text { clinopyroxene, } 7 \% \text { olivine, trace titanoilmenite, } 5 \% \text { amphibole, } 1 \% \text { talc and chlorite. Probably the most altered sample in } \\
\text { the suite. Medium grained, adcumulate texture. }\end{array}$ \\
\hline $9 \mathrm{R}-2,70$ & $\begin{array}{l}\text { Olivine gabbro. } 69 \% \text { plagioclase, } 23 \% \text { olivine, } 7 \% \text { clinopyroxene, trace titanoilmenite. } 2 \% \text { total alteration minerals comprised of amphibole, clay, chlorite and talc. } \\
\text { Some olivine is very coarse grained (to } 10 \mathrm{~mm} \text { ). Medium to coarse grained, crescumulate textured. }\end{array}$ \\
\hline $10 \mathrm{R}-1,40$ & $\begin{array}{l}\text { Olivine gabbro. } 60 \% \text { plagioclase, } 39 \% \text { clinopyroxene, } 9 \% \text { olivine, trace titanoilmenite. Nearly fresh rock ( } 1 \% \text { amphibole). Plagioclase exhibits distinct } \\
\text { recrystallization as grain-size reduction. Medium grained, adcumulate textured. }\end{array}$ \\
\hline 10R-1, 106 & $\begin{array}{l}\text { Olivine gabbro. } 64 \% \text { plagioclase, } 22 \% \text { clinopyroxene, } 9 \% \text { olivine, trace titanoilmenite. } 4 \% \text { total alteration as amphibole, talc, and chlorite. Well-preserved } \\
\text { adcumulate texture in a coarse-grained rock. Olivine and clinopyroxene have partially surrounded plagioclase crystals in subophitic to poikilitic texture. }\end{array}$ \\
\hline 10R-3, 44 & $\begin{array}{l}\text { Olivine gabbro. } 60 \% \text { plagioclase, } 29 \% \text { clinopyroxene, } 9 \% \text { olivine, trace titanoilmenite. } 2 \% \text { total alteration to clay and amphibole. Texture completely } \\
\text { recrystallized. Medium grained. }\end{array}$ \\
\hline $11 \mathrm{R}-1,55$ & $\begin{array}{l}\text { Olivine gabbro. Paired core (Sample } 153-923 \mathrm{~A}-11 \mathrm{R}-1,69 \mathrm{~cm} \text { ) is identical. } 60 \% \text { plagioclase, } 31 \% \text { clinopyroxene, } 7 \% \text { olivine, trace titanoilmenite. } 2 \% \text { total } \\
\text { alteration to amphibole. Strongly recrystallized, fine-grained, gneissic texture. }\end{array}$ \\
\hline $11 \mathrm{R}-2,56$ & $\begin{array}{l}\text { Gabbro. } 55 \% \text { plagioclase, } 39 \% \text { clinopyroxene ( } 4 \% \text { may be secondary, interstitial fine-grained habit), } 4 \% \text { olivine, trace titanoilmenite, } 1 \% \text { amphibole. Large } \\
\text { clinopyroxene grains are mildly ophitic ( } 1 \text { to } 2 \text { plagioclase grains as chadacrysts). No preferred fabric, but distinct recrystallization texture exhibited as grain-size } \\
\text { reduction in plagioclase and clinopyroxene. }\end{array}$ \\
\hline $12 \mathrm{R}-1,120$ & $\begin{array}{l}\text { Troctolite. Paired core (Sample } 153-923 \mathrm{~A}-12 \mathrm{R}-1,126 \mathrm{~cm} \text { ) is identical. } 70 \% \text { plagioclase, } 26 \% \text { olivine, } 2 \% \text { pyroxene, } 2 \% \text { alteration to magnetite, chlorite, and talc } \\
\text { after olivine. Crescumulate textured, coarse grained. Pyroxene only occurs as mantles around olivine and as small interstitial grains. }\end{array}$ \\
\hline $12 \mathrm{R}-2,41$ & $\begin{array}{l}\text { Olivine gabbro. } 60 \% \text { plagioclase, } 19 \% \text { clinopyroxene, } 18 \% \text { olivine, trace titanoilmenite. } 3 \% \text { total alteration to amphibole, talc, chlorite, and magnetite. Cumulate } \\
\text { textured, possibly some orthopyroxene as reaction rims around olivine. Clinopyroxene and olivine are commonly intergrown. Medium grained. }\end{array}$ \\
\hline $13 \mathrm{R}-1,114$ & $\begin{array}{l}\text { Olivine gabbro. } 50 \% \text { plagioclase, } 33 \% \text { clinopyroxene } 13 \% \text { olivine, trace titanoilmenite, } 4 \% \text { alteration to amphibole, talc, and magnetite. Clearly recrystallized and } \\
\text { one of the more pervasively altered samples. }\end{array}$ \\
\hline $13 \mathrm{R}-3,50$ & $\begin{array}{l}\text { Olivine gabbro. } 65 \% \text { plagioclase, } 19 \% \text { clinopyroxene, } 13 \% \text { olivine, trace titanoilmenite. } 3 \% \text { total alteration to amphibole, talc, chlorite, and magnetite. Cumulate } \\
\text { textured, medium grained. }\end{array}$ \\
\hline $14 \mathrm{R}-1,55$ & $\begin{array}{l}\text { Troctolite. } 69 \% \text { plagioclase, } 28 \% \text { olivine, } 1 \% \text { clinopyroxene, } 2 \% \text { total alteration to magnetite, clay, and talc. Only contains a couple small grains of pyroxene. } \\
\text { Coarse grained, adcumulate textured. }\end{array}$ \\
\hline $14 \mathrm{R}-2,6$ & Olivine gabbro. $75 \%$ plagioclase, $17 \%$ clinopyroxene, $6 \%$ olivine, $2 \%$ alteration as amphibole. Medium grained, adcumulate textured. \\
\hline $15 \mathrm{R}-2,88$ & $\begin{array}{l}\text { Troctolite. } 82 \% \text { plagioclase, } 14 \% \text { olivine, } 2 \% \text { clinopyroxene, trace titanoilmenite, } 2 \% \text { alteration to amphibole, talc, chlorite, and magnetite. Olivine-plagioclase } \\
\text { boundaries commonly marked by amphibole. Medium grained, adcumulate textured. }\end{array}$ \\
\hline $16 \mathrm{R}-2,2$ & $\begin{array}{l}\text { Olivine gabbro. } 72 \% \text { plagioclase, } 17 \% \text { clinopyroxene, } 6 \% \text { olivine, trace titanoilmenite, } 5 \% \text { alteration to amphibole, clay, and magnetite. Most oikocrystic looking } \\
\text { sample in the suite. Coarse grained, cumulate textured. }\end{array}$ \\
\hline $16 \mathrm{R}-3,42$ & $\begin{array}{l}\text { Olivine gabbro. } 80 \% \text { plagioclase, } 11 \% \text { clinopyroxene, } 6 \% \text { olivine, trace titanoilmenite, } 3 \% \text { alteration to amphibole, talc, chlorite, and magnetite. Cumulate } \\
\text { textured, medium grained. }\end{array}$ \\
\hline
\end{tabular}

creasing $V_{p}$. According to this figure, as any combination of olivine and orthopyroxene undergoes the serpentinization reaction, velocity should decrease sharply. Much of the data from the serpentinized peridotites at MARK fall outside of the triangle formed by the average velocity-density values of the three principal phases. We surmise this is due to a by-product according to the serpentinization reaction:

$$
\text { olivine + orthopyroxene + water }
$$$$
=\text { brucite }+ \text { serpentine }+ \text { magnetite } \text {. }
$$

Because of its high density, even a few percent magnetite produced by this reaction can raise the densities of these samples high enough to push the data out of the serpentine-orthopyroxene-olivine envelope.

\section{Elastic Constants}

$V_{p} / V_{s}$, Poisson's ratios $(\sigma)$, bulk moduli $(K)$, and shear moduli $(\mu)$ calculated at various pressures and measured densities and velocities are presented in Tables 5 and 6 . These values must be considered in drilling operations because microfracture density (thus, by analogy, ease in drilling) is generally proportional to the elastic moduli
(O'Connell and Budiansky, 1974). Pre-existing fractures and planes of weakness reduce the effective elastic stiffness of the rock, and allow the drill bit purchase and a point for failure to initiate. Elastic moduli are defined as:

Poisson's ratio $(\sigma)=$ lateral contraction $\times$ longitudinal extension

$$
=\left(V_{p}^{2}-2 V_{s}^{2}\right) /\left[2\left(V_{p}^{2}-V_{s}^{2}\right)\right]
$$

bulk moduli $(K)=$ change in pressure $\times$ change in volume

$$
=\rho\left[V_{p}^{2}-(4 / 3) V_{s}^{2}\right]
$$

$$
\text { shear moduli }(\mu)=\text { shear stress } \times \text { shear strain }=\rho\left(V_{s}^{2}\right)
$$

where $\rho=$ density. Evaluation of elastic moduli for various crustal rock types exposed on the seafloor can provide information regarding drill bit life and potential drilling difficulty.

Although $\sim 90 \%$ of remote geophysical velocity data is $V_{p}$, the ratio of $V_{p}$ to $V_{s}$ (when both are available) has been invoked as a lithology discriminant (e.g., Tatham, 1982; Wilkens et al., 1984; Elo and Korja, 1993). An examination of laboratory-measured $V_{p} / V_{s}$ plotted relative to density reveals that the gabbroic rocks and serpentinized 


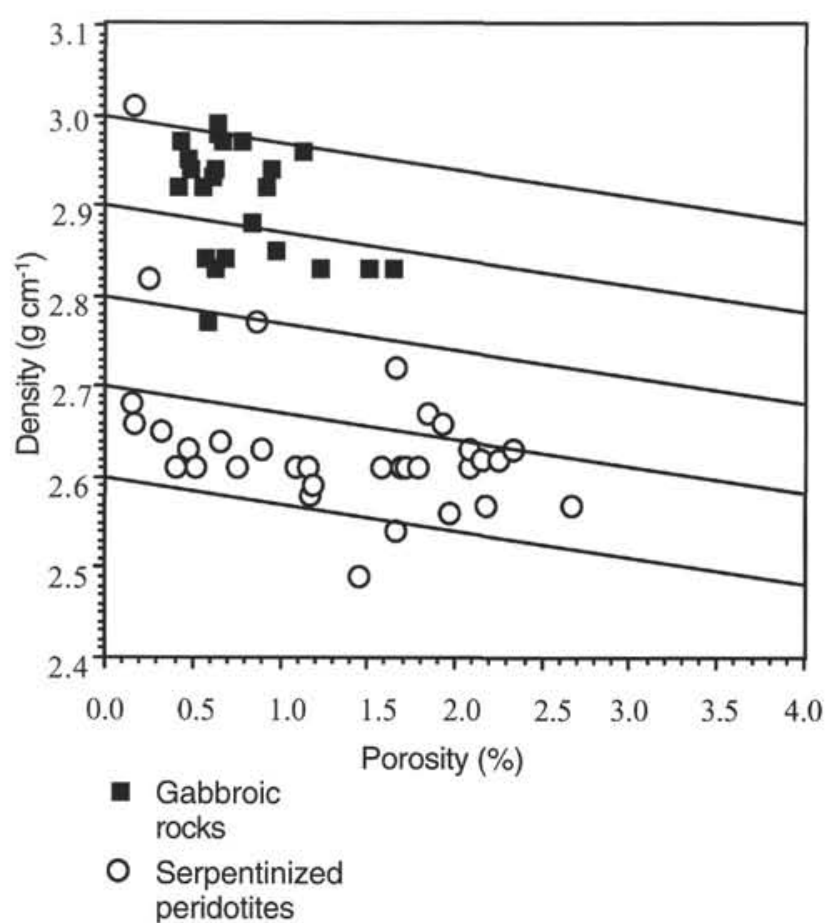

Figure 5. Density-porosity relationship for all samples examined in this study. Contours are calculated change in density purely as a function of increasing porosity.

peridotites sampled at the Southwest Indian Ridge, Hess Deep, and MARK fall into two, relatively distinct fields (Fig. 12). It is interesting to note, however, that the least serpentinized peridotites from both Hess Deep and MARK show evidence of merging into the field delineated by the gabbroic rock data, and that several partially serpentinized samples from the MARK area are indistinguishable in $V_{p} /$ $V_{s}$-density space from the gabbroic rocks. The potential difficulty in distinguishing partially serpentinized peridotite from gabbro is illustrated in Figure 13. The dark stippled field represents the range of all $V_{p}$-density data for gabbroic rocks sampled from Southwest Indian Ridge (Leg 118), Hess Deep (Leg 147), and MARK (Leg 153). The light stippled field represents the range of $V_{p}$ and density of peridotites that are $30 \%$ to $50 \%$ serpentinized, as calculated from regression parameters for all the peridotites considered in this study. This suggests that caution must be exercised when interpreting remote seismic data in terms of thickness of the oceanic crust, as partially serpentinized peridotite may have physical properties that render it indistinguishable from lower crustal gabbro.

A plot of the $V_{p}-V_{s}$ data contoured in terms of Poisson's ratio (Fig. 14) shows that the gabbroic rocks from MARK have a welldefined, narrow range of values. Nearly all the $\sigma$ values fall between 0.25 and 0.30 , with a mean of 0.29 and a standard deviation of 0.01 . This value is in excellent agreement with $\sigma$ derived from ophiolitic gabbros (Christensen, 1978) and oceanic gabbroic rocks sampled at the Southwest Indian Ridge (Iturrino, et al., 1991) and Hess Deep (Iturrino et al., 1996).

Turning to values for serpentinized peridotites plotted in the same field, we note that there is a much broader range $(0.25$ to 0.40$)$ and a significantly higher mean and standard deviation $(0.35 \pm 0.03)$ than shown for gabbroic rocks. These are consistent with oceanic upper mantle values published by Christensen (1974).

Examining other elastic constants from these data, we can evaluate potential reasons for the variability in drilling characteristics between the Southwest Indian Ridge (Leg 118), Hess Deep (Leg 147), and MARK. Drilling operations during Leg 118 experienced nearly $100 \%$ recovery from Hole $735 \mathrm{~B}$, which penetrated in excess of 500 $\mathrm{m}$ of gabbro. Downhole conditions precluded such phenomenal recovery and penetration at both Hess Deep (Site 894) and MARK
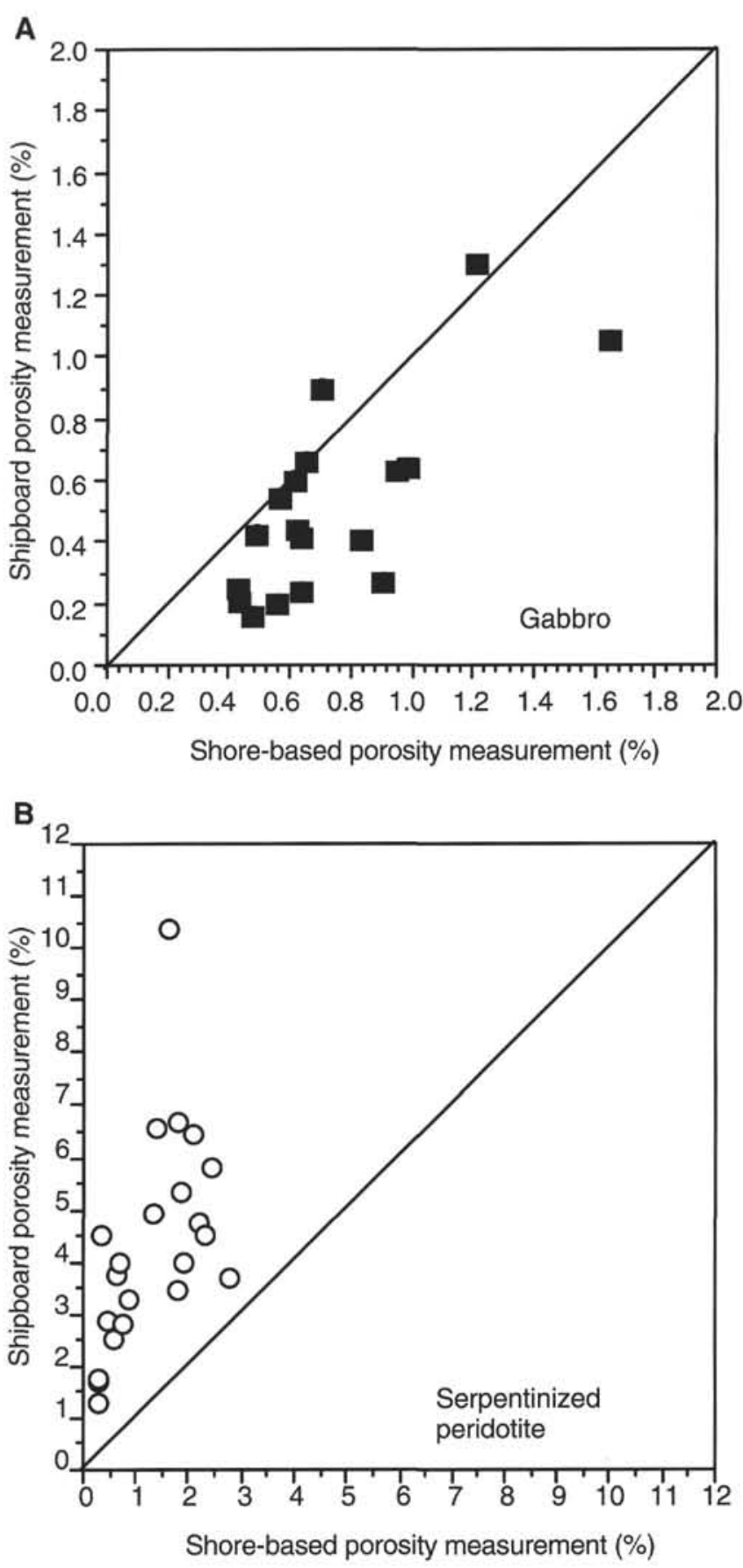

Figure 6. Change in porosity with time for (A) gabbroic rocks and (B) serpentinized peridotites. Lines represent 1:1 correspondence for illustrative purposes.

(Sites 921-924). If we examine the bulk moduli $(K)$ and shear moduli ( $\mu$ ) data (Table 7) for all three sites, we note that $\mu$ is constant. There is, however, a statistical difference in $K$, with the mean $K$ for MARK higher than the same value in samples from either the Southwest Indian Ridge or Hess Deep. Inasmuch as the shear modulus is the force per unit area divided by change in length and the bulk modulus is the force per unit area divided by change in volume, this indicates we are seeing a difference in the change in volume not reflected in the change in length of the sample. If a rock contains more abundant microcracks the potential for a change in volume is greater and a lower $K$ value will result. From these data, the change in volume of the samples from the MARK area is less than from the other areas, indicating potentially fewer in situ microcracks, or points of purchase for the 


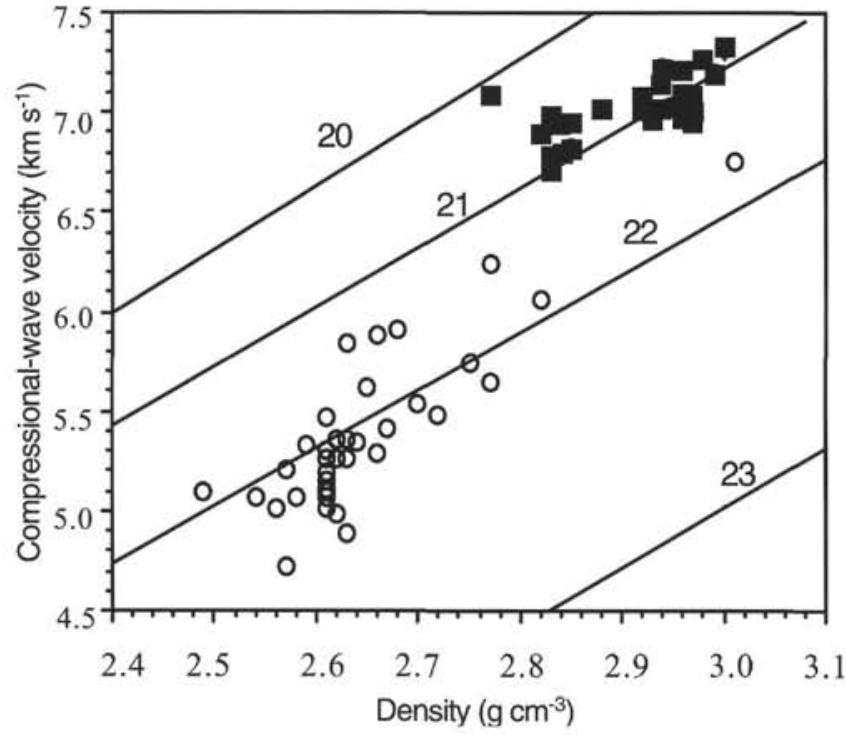

Figure 7. Velocity-density relationship for all samples analyzed. Contours are lines of constant mean atomic weight. Solid squares represent data from gabbroic rocks, open circles represent data from serpentinized peridotite.

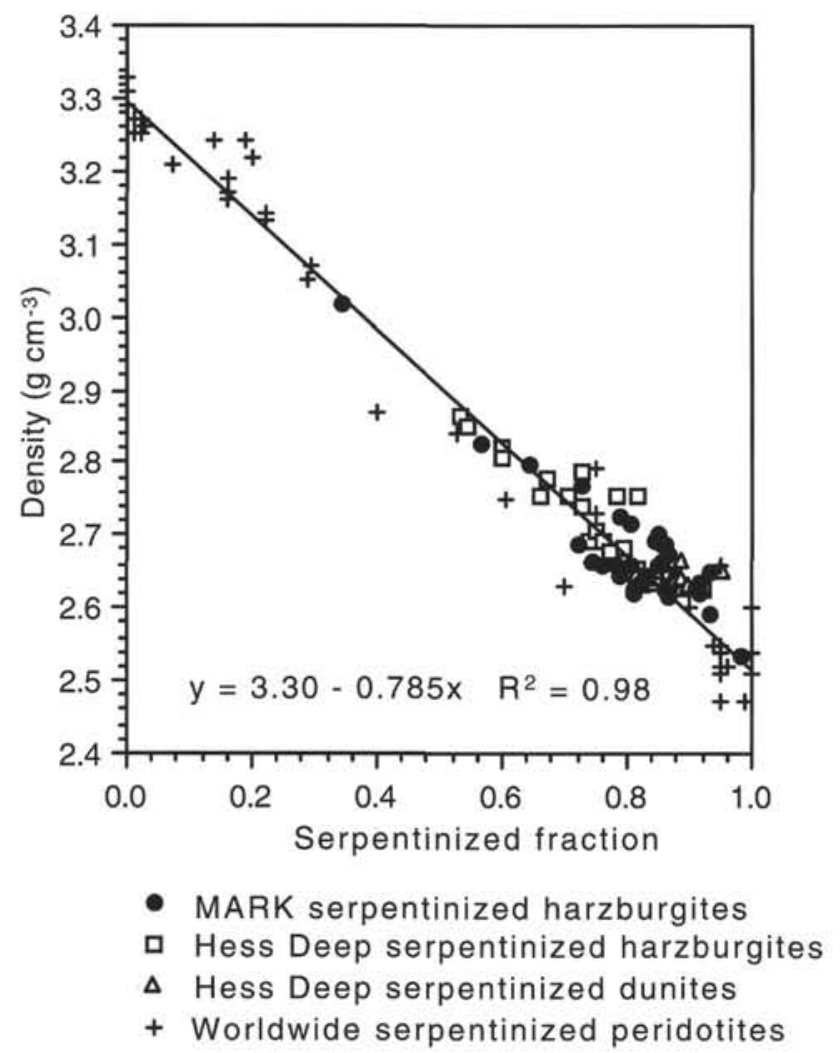

Figure 8. Density plotted relative to degree of serpentinization. Data from worldwide serpentinites are taken from Christensen $(1966,1972,1978)$, Christensen and Salisbury (1972), and Kroenke et al., (1976). Data from Hess Deep rocks are taken from Iturrino et al., (1996).

drill bit. Although this will likely lead to more demanding drilling conditions, it could mean an inherently more stable hole. We note that coring proceeded slowly (less than $0.3 \mathrm{~m}$ per hour) during operations at Hole $923 \mathrm{~A}$, however recovery was nearly $75 \%$ (Cannat, Karson, Miller, et al., 1995). Although drilling parameters at Site 923 indicated a clean and stable hole, the gabbroic rocks were extremely abrasive, causing rapid deterioration of drill bits. Hence, deepening

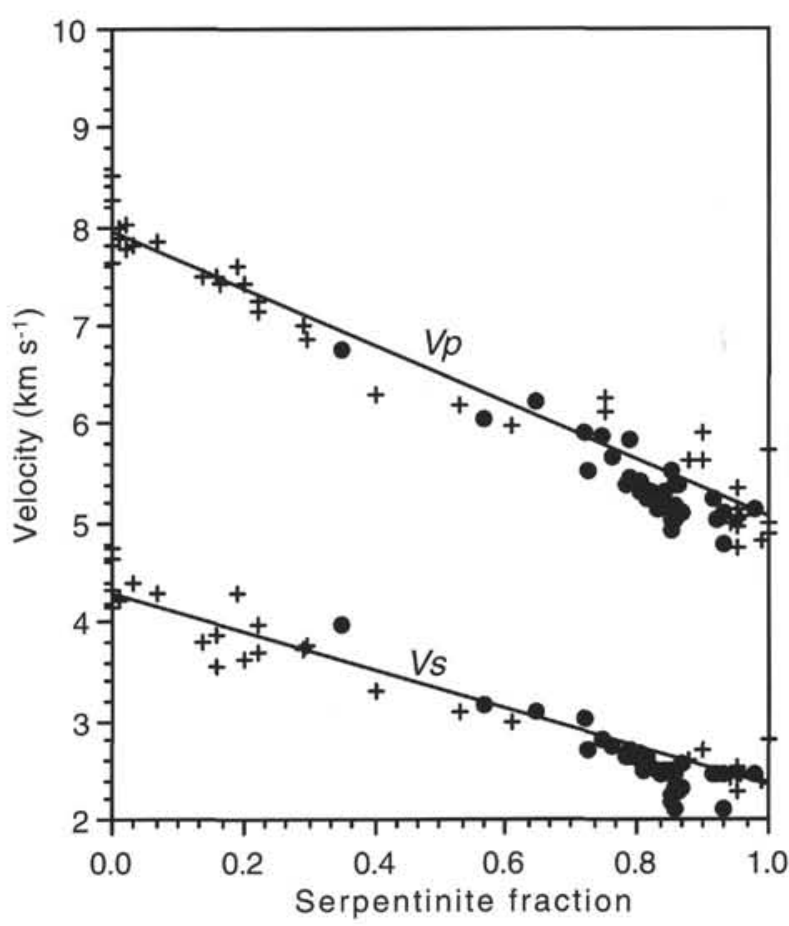

- MARK serpentinized peridotites

+ Worldwide serpentinized peridotites

Figure 9. Compressional- and shear-wave velocity plotted with respect to degree of serpentinization. Data from worldwide serpentinized peridotites are taken from same sources as Figure 8.

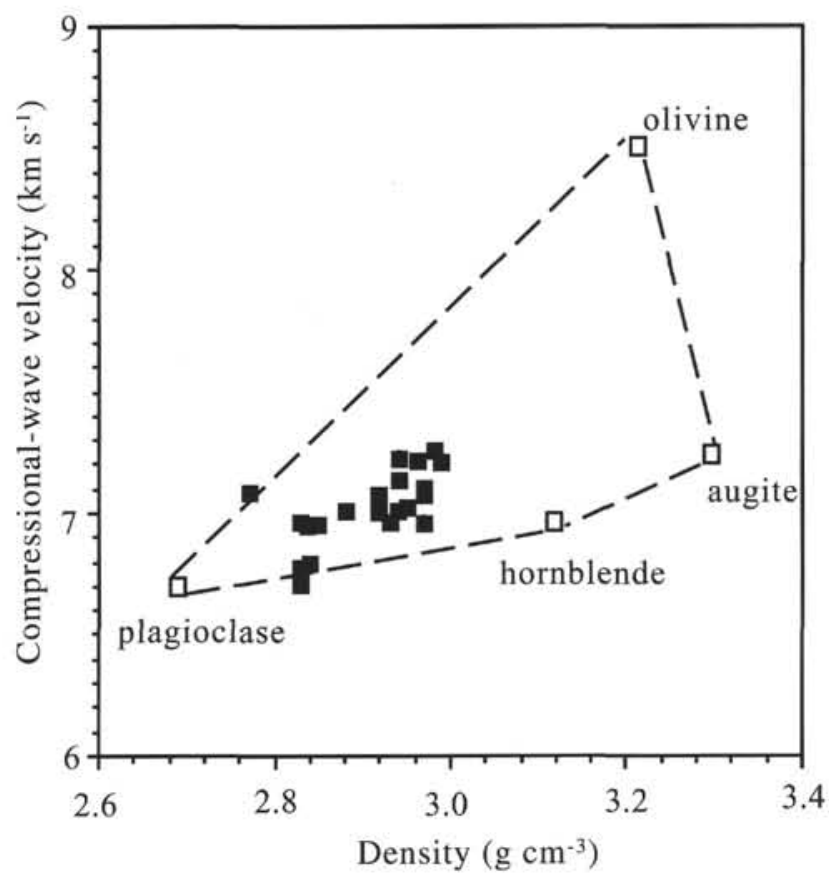

Figure 10, VRH plot for MARK gabbroic rocks. VRH averages are from Christensen (1982).

holes in this type of environment requires multiple pipe trips to replace drill bits. Existing reentry templates, however, restrict operations to areas with only minor topographic undulation and relief. New drilling tools and adaptations of existing technology have the potential of overcoming these restrictions, allowing significantly greater penetration and recovery. 


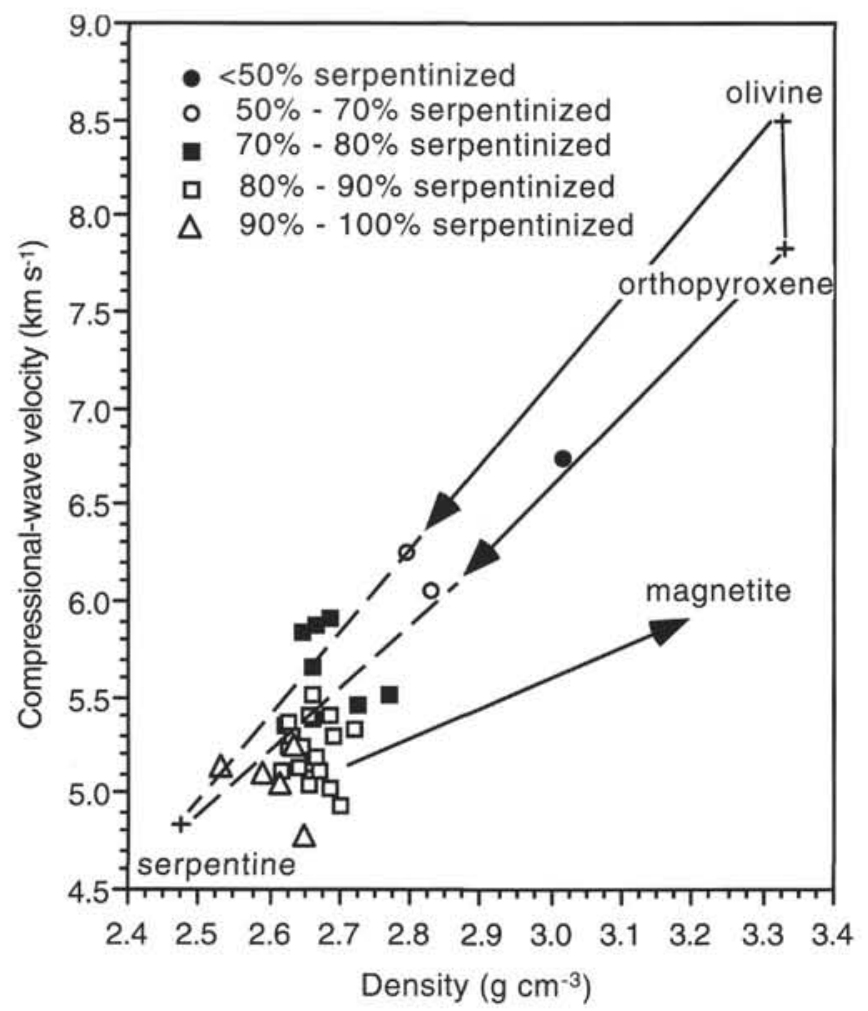

Figure 11. VRH-type plot for MARK serpentinized peridotites. VRH averages for olivine and orthopyroxene are from Christensen (1982), serpentine values are averaged from Christensen $(1966,1972,1978)$.

\section{SUMMARY}

Serpentinized peridotites and gabbroic rocks outcrop along the western median valley wall of the Mid-Atlantic Ridge, south of the Kane Transform. Physical properties measurements have led us to the following conclusions regarding the nature of the lower oceanic crust and upper mantle at a slow-spreading mid-ocean ridge.

1. Whereas porosity is seen to increase slightly or remain nearly the same with time in gabbroic rocks, serpentinized peridotites exhibit a marked decrease in porosity over the same time interval. Removal of the present day lithostatic and hydrostatic load (in excess of $40 \mathrm{MPa}$ ) from the core should allow microcrack propagation, as evidenced by the slight increase in porosity common to gabbroic samples. Similar microcrack propagation is probably ongoing in the serpentinized peridotites, however, expansion of serpentine fills the cracks rapidly. This expansion may be caused by either latent volumetric expansion of the serpentinization reaction or continuing serpentinization. This expansion may contribute to drilling difficulty, suggesting that steps should be taken to isolate the hole once drilled (i.e., casing).

2. Velocity-density relationships support the petrographic interpretation that the gabbroic rocks from MARK are significantly fresher than similar lithologies from the fast-spreading ridge near Hess Deep. This is reflected in higher velocities at any given density. Values of MAW (estimated from velocitydensity covariation) for MARK gabbroic rocks are identical to values derived from samples taken during Leg 118, at the ultra-slow-spreading Southwest Indian Ridge. Velocity-density relationships for samples taken from the serpentinite ridge at MARK are indistinguishable from similar data on serpentinized peridotites from near Hess Deep.
3. There is a strong negative correlation between seismic velocity $\left(V_{p}\right.$ and $\left.V_{s}\right)$ and degree of serpentinization in samples from ophiolite sequences worldwide. Data from serpentinized peridotites at MARK duplicate this trend, suggesting the potential of estimating the degree of serpentinization from $V_{p}$ and $V_{s}$ measurements. However, practical application of these parameters to petrologic interpretations rely on the nontrivial restrictions imposed by the resolution of remote geophysical velocity data. The maximum resolution of lower crustal/upper mantle velocity surveys (data integration over minimally $1000 \mathrm{~m}$ ) exceeds by half an order of magnitude the total length penetrated at Hole 920D. Within the samples recovered from this hole, there is evidence of extreme heterogeneity in the degree of serpentinization.

4. Data from gabbroic samples fall within a field defined by the $\mathrm{VRH}$ averages for $\mathrm{An}_{56}$ plagioclase, olivine, augite, and hornblende, and most fall within the plagioclase-olivine-augite triangle. A single troctolite examined plots on the plagioclaseolivine join. An estimate from VRH averages of the relative proportions of minerals necessary to produce the data array observed is in excellent agreement with petrographic analysis This suggests the utility of using velocities to estimate the mineralogical composition of the crust, given a reliable density estimate. The caveat regarding local-scale heterogeneity and the resolution of remote velocity surveys applies to gabbroic rocks as it does to serpentinized peridotites.

5. A VRH-type plot for serpentinized peridotites from MARK shows that, whereas some of the data fall in the triangle defined by olivine and orthopyroxene VRH averages, and the average serpentine velocity-density value, much of the data is shifted to higher densities. This is likely due to the generation of magnetite in the serpentinization reaction. This analysis also points out one of the pitfalls of using velocity data to estimate crustal components. Although data from completely fresh and completely serpentinized peridotite fall in distinct and separate fields, according to these data, a peridotite that has undergone $30 \%-35 \%$ serpentinization is indistinguishable in terms of $V_{p}, V_{s}$ or density from the field defined by gabbroic rocks recovered on Legs 118, 147, and 153. Even peridotite samples with $50 \%$ serpentinization merge into the field occupied by data from gabbroic rocks. $V_{p} / V_{s}$ values, used to interpret remote seismic data, are indistinguishable as well in peridotites with only moderate serpentinization. Samples with this mineralogy are present in the MARK sample suite, and are probably present at depth in the oceanic crustal section at MARK. This will cloud interpretation from remote geophysical velocity studies in terms of locating boundaries between gabbro and peridotite in the ocean crust.

6. The relationship between bulk moduli and shear moduli for the gabbroic rocks from MARK compared to other regions in the ocean where gabbros have been drilled suggests that, although drilling at MARK may be more difficult, the rocks may have physical properties that lead to a more coherent hole. This interpretation complements shipboard observations that indicated some of the holes were in reasonably good condition, and limitations on reentry capability, not poor drilling conditions, limited penetration at Site 923.

Two primary results of this investigation regarding the future of drilling deep crustal sections in the world's ocean basins merit attention. First, drilling either in peridotites or in gabbros requires a reentry template. Although peridotites drill rapidly and with minimal bit wear, the drill string must be isolated from the borehole walls to prevent collapse and binding. In gabbroic rocks that have physical properties that resist fracturing, which leads to slower penetration rates and exacerbated wear in drill bits, several bit changes will be required 
Table 5. Elastic constants for samples from Hole 920D.

\begin{tabular}{|c|c|c|c|c|c|c|c|c|c|}
\hline $\begin{array}{l}\text { Core, section, } \\
\text { interval }(\mathrm{cm}) \\
\text { Lithology }\end{array}$ & Mode & $\begin{array}{c}20 \\
\mathrm{MPa}\end{array}$ & $\begin{array}{c}40 \\
\mathrm{MPa}\end{array}$ & $\begin{array}{c}60 \\
\mathrm{MPa}\end{array}$ & $\begin{array}{c}80 \\
\mathrm{MPa}\end{array}$ & $\begin{array}{c}100 \\
\mathrm{MPa}\end{array}$ & $\begin{array}{c}200 \\
\mathrm{MPa}\end{array}$ & $\begin{array}{c}300 \\
\mathrm{MPa}\end{array}$ & $\begin{array}{c}400 \\
\mathrm{MPa}\end{array}$ \\
\hline 153-920D- & & & & & & & & & \\
\hline $2 \mathrm{R}-1,116-119$ & $V_{s} N_{s}$ & 1.817 & 1.734 & 1.711 & 1.705 & 1.704 & 1.706 & 1.709 & 1.712 \\
\hline Serpentinized harzburgite & $\sigma$ & 0.283 & 0.251 & 0.241 & 0.238 & 0.237 & 0.238 & 0.240 & 0.241 \\
\hline & $K$ & 0.763 & 0.728 & 0.722 & 0.723 & 0.727 & 0.743 & 0.755 & 0.765 \\
\hline & $\mu$ & 0.388 & 0.436 & 0.453 & 0.460 & 0.463 & 0.471 & 0.475 & 0.478 \\
\hline $3 R-1,49-52$ & $V_{p} / V_{s}$ & 2.043 & 2.010 & 1.995 & 1.988 & 1.987 & 1.997 & 2.006 & 2.014 \\
\hline Serpentinized harzburgite & $\sigma$ & 0.343 & 0.336 & 0.332 & 0.331 & 0.330 & 0.333 & 0.335 & 0.336 \\
\hline & $K$ & 0.443 & 0.450 & 0.453 & 0.457 & 0.461 & 0.476 & 0.487 & 0.495 \\
\hline & $\mu$ & 0.156 & 0.166 & 0.171 & 0.175 & 0.176 & 0.180 & 0.181 & 0.182 \\
\hline $4 \mathrm{R}-3,35-38(\mathrm{H})$ & $V, N$ & 2.071 & 2.043 & 2.031 & 2.028 & 2.031 & 2.050 & 2.068 & 2.083 \\
\hline Serpentinized harzburgite & $\sigma$ & 0.348 & 0.343 & 0.340 & 0.339 & 0.340 & 0.344 & 0.347 & 0.350 \\
\hline & K & 0.474 & 0.485 & 0.492 & 0.497 & 0.503 & 0.523 & 0.539 & 0.552 \\
\hline & $\mu$ & 0.160 & 0.171 & 0.176 & 0.179 & 0.180 & 0.182 & 0.183 & 0.184 \\
\hline $4 \mathrm{R}-3,38-41(\mathrm{~V})$ & $V_{p}$ & 2.033 & 2.014 & 2.005 & 2.005 & 2.007 & 2.030 & 2.050 & 2.065 \\
\hline Serpentinized harzburgite & $\sigma$ & 0.340 & 0.336 & 0.335 & 0.334 & 0.335 & 0.340 & 0.344 & 0.347 \\
\hline & $K$ & 0.477 & 0.485 & 0.489 & 0.494 & 0.498 & 0.520 & 0.537 & 0.549 \\
\hline & $\mu$ & 0.170 & 0.178 & 0.182 & 0.184 & 0.185 & 0.186 & 0.187 & 0.187 \\
\hline $5 R-3,20-23$ & ${ }_{V}^{\mu}$ & 2.175 & 2.149 & 2.139 & 2.135 & 2.136 & 2.156 & 2.175 & 2.192 \\
\hline Serpentinized harzburgite & $\sigma$ & 0.366 & 0.362 & 0.360 & 0.359 & 0.360 & 0.363 & 0.366 & 0.369 \\
\hline & $K$ & 0.492 & 0.498 & 0.503 & 0.507 & 0.512 & 0.533 & 0.548 & 0.561 \\
\hline & $\mu$ & 0.145 & 0.151 & 0.155 & 0.157 & 0.159 & 0.161 & 0.161 & 0.162 \\
\hline $5 R-3,127-131$ & $V_{p} / V_{s}$ & 1.965 & 1.983 & 1.993 & 2.002 & 2.010 & 2.041 & 2.062 & 2.078 \\
\hline Serpentinized harzburgite & $\sigma$ & 0.325 & 0.329 & 0.332 & 0.334 & 0.336 & 0.342 & 0.346 & 0.349 \\
\hline & K & 0.380 & 0.396 & 0.405 & 0.413 & 0.420 & 0.444 & 0.459 & 0.471 \\
\hline & $\mu$ & 0.150 & 0.152 & 0.154 & 0.154 & 0.155 & 0.157 & 0.157 & 0.158 \\
\hline $5 R-4,93-97$ & $\hat{V}_{\Delta}$ & 2.139 & 2.168 & 2.182 & 2.190 & 2.197 & 2.227 & 2.247 & 2.262 \\
\hline Serpentinized harzburgite & $\sigma$ & 0.360 & 0.365 & 0.367 & 0.368 & 0.369 & 0.374 & 0.377 & 0.379 \\
\hline & $K$ & 0.418 & 0.450 & 0.467 & 0.478 & 0.487 & 0.514 & 0.529 & 0.541 \\
\hline & $\mu$ & 0.129 & 0.134 & 0.136 & 0.138 & 0.139 & 0.142 & 0.142 & 0.143 \\
\hline $6 \mathrm{R}-1,53-56(\mathrm{H})$ & $V_{p}$ & 1.991 & 1.974 & 1.966 & 1.965 & 1.968 & 1.994 & 2.014 & 2.028 \\
\hline Serpentinized harzburgite & $\sigma^{p}$ & 0.331 & 0.327 & 0.326 & 0.325 & 0.326 & 0.332 & 0.336 & 0.339 \\
\hline & $K$ & 0.367 & 0.389 & 0.401 & 0.410 & 0.419 & 0.448 & 0.467 & 0.482 \\
\hline & $\mu$ & 0.139 & 0.152 & 0.158 & 0.162 & 0.165 & 0.170 & 0.172 & 0.173 \\
\hline $6 \mathrm{R}-1,58-61(\mathrm{~V})$ & $V_{p}$ & 2.112 & 2.041 & 2.013 & 2.005 & 2.004 & 2.026 & 2.047 & 2.065 \\
\hline Serpentinized harzburgite & $\sigma$ & 0.356 & 0.342 & 0.336 & 0.335 & 0.334 & 0.339 & 0.343 & 0.347 \\
\hline & $K$ & 0.407 & 0.409 & 0.412 & 0.418 & 0.423 & 0.449 & 0.469 & 0.485 \\
\hline & $\mu$ & 0.130 & 0.144 & 0.152 & 0.155 & 0.158 & 0.162 & 0.164 & 0.166 \\
\hline $7 \mathrm{R}-1,124-128$ & $V_{\Delta}$ & 2.089 & 2.096 & 2.095 & 2.092 & 2.090 & 2.091 & 2.100 & 2.108 \\
\hline Serpentinized harzburgite & $\sigma$ & 0.351 & 0.353 & 0.352 & 0.352 & 0.352 & 0.352 & 0.353 & 0.355 \\
\hline & $K$ & 0.383 & 0.411 & 0.426 & 0.435 & 0.441 & 0.456 & 0.466 & 0.473 \\
\hline & $\mu$ & 0.126 & 0.134 & 0.139 & 0.143 & 0.145 & 0.150 & 0.151 & 0.152 \\
\hline $8 \mathrm{R}-1,136-139(\mathrm{~V})$ & $\hat{V}_{\Delta}$ & 2.108 & 2.090 & 2.085 & 2.087 & 2.093 & 2.124 & 2.147 & 2.163 \\
\hline Serpentinized harzburgite & $\sigma$ & 0.355 & 0.352 & 0.351 & 0.351 & 0.352 & 0.358 & 0.361 & 0.364 \\
\hline & K & 0.449 & 0.458 & 0.465 & 0.472 & 0.479 & 0.504 & 0.522 & 0.534 \\
\hline & $\ddot{\mu}$ & 0.144 & 0.151 & 0.154 & 0.156 & 0.157 & 0.159 & 0.159 & 0.160 \\
\hline $8 \mathrm{R}-1,141-144(\mathrm{H})$ & $V_{t}$ & 2.080 & 2.073 & 2.071 & 2.072 & 2.074 & 2.089 & 2.105 & 2.118 \\
\hline Serpentinized harzburgite & $\sigma$ & 0.350 & 0.348 & 0.348 & 0.348 & 0.349 & 0.351 & 0.354 & 0.357 \\
\hline & $K$ & 0.468 & 0.475 & 0.481 & 0.486 & 0.491 & 0.510 & 0.525 & 0.538 \\
\hline & $\mu$ & 0.156 & 0.160 & 0.163 & 0.164 & 0.165 & 0.168 & 0.170 & 0.171 \\
\hline $8 \mathrm{R}-3,74-77$ & $V_{p}$ & 1.917 & 1.951 & 1.954 & 1.948 & 1.942 & 1.922 & 1.919 & 1.920 \\
\hline Diabase & $\sigma^{\prime \prime}$ & 0.313 & 0.322 & 0.322 & 0.321 & 0.320 & 0.315 & 0.314 & 0.314 \\
\hline & $K$ & 0.444 & 0.492 & 0.511 & 0.520 & 0.525 & 0.537 & 0.546 & 0.554 \\
\hline & $\mu$ & 0.189 & 0.199 & 0.206 & 0.211 & 0.215 & 0.227 & 0.233 & 0.236 \\
\hline $9 \mathrm{R}-2,52-55$ & $\hat{V}_{t}$ & 1.843 & 1.858 & 1.865 & 1.869 & 1.873 & 1.884 & 1.890 & 1.895 \\
\hline Diabase & $\sigma$ & 0.291 & 0.296 & 0.298 & 0.300 & 0.301 & 0.304 & 0.306 & 0.307 \\
\hline & $K$ & 0.461 & 0.486 & 0.501 & 0.513 & 0.522 & 0.551 & 0.567 & 0.578 \\
\hline & $\mu$ & 0.223 & 0.229 & 0.234 & 0.237 & 0.240 & 0.249 & 0.253 & 0.256 \\
\hline $10 \mathrm{R}-1,49-52(\mathrm{~V})$ & $V_{t}$ & 2.017 & 2.069 & 2.093 & 2.105 & 2.112 & 2.123 & 2.124 & 2.124 \\
\hline Diabase & $\sigma^{p}$ & 0.337 & 0.348 & 0.352 & 0.354 & 0.355 & 0.357 & 0.358 & 0.358 \\
\hline & $K$ & 0.509 & 0.558 & 0.584 & 0.600 & 0.610 & 0.638 & 0.652 & 0.663 \\
\hline & $\mu$ & 0.186 & 0.189 & 0.192 & 0.194 & 0.195 & 0.201 & 0.205 & 0.209 \\
\hline $10 \mathrm{R}-1,54-5(\mathrm{H})$ & $V_{p}$ & 1.784 & 1.784 & 1.783 & 1.882 & 1.877 & 1.865 & 1.860 & 1.857 \\
\hline Diabase & $\sigma^{\prime \prime}$ & 0.271 & 0.271 & 0.270 & 0.303 & 0.302 & 0.298 & 0.297 & 0.296 \\
\hline & $K$ & 0.339 & 0.354 & 0.362 & 0.441 & 0.443 & 0.454 & 0.463 & 0.472 \\
\hline & $\mu$ & 0.183 & 0.192 & 0.196 & 0.200 & 0.203 & 0.212 & 0.218 & 0.223 \\
\hline $10 \mathrm{R}-4,80-83$ & $V_{d} / N$ & 1.976 & 1.963 & 1.957 & 1.956 & 1.957 & 1.965 & 1.972 & 1.978 \\
\hline Serpentinized harzburgite & $\sigma^{p}$ & 0.328 & 0.325 & 0.323 & 0.323 & 0.323 & 0.325 & 0.327 & 0.328 \\
\hline & $K$ & 0.556 & 0.569 & 0.578 & 0.585 & 0.591 & 0.612 & 0.624 & 0.633 \\
\hline & $\mu$ & 0.216 & 0.226 & 0.231 & 0.235 & 0.237 & 0.242 & 0.244 & 0.246 \\
\hline $11 \mathrm{R}-1,27-30$ & $V, N$ & 1.933 & 1.949 & 1.958 & 1.966 & 1.974 & 2.001 & 2.017 & 2.029 \\
\hline Serpentinized harzburgite & $\sigma$ & 0.317 & 0.321 & 0.324 & 0.326 & 0.327 & 0.334 & 0.337 & 0.340 \\
\hline & $K$ & 0.363 & 0.379 & 0.388 & 0.396 & 0.402 & 0.426 & 0.441 & 0.452 \\
\hline & $\ddot{\mu}$ & 0.151 & 0.154 & 0.155 & 0.156 & 0.157 & 0.160 & 0.161 & 0.162 \\
\hline $11 \mathrm{R}-1,125-128(\mathrm{H})$ & $V_{f}$ & 1.857 & 1.871 & 1.882 & 1.891 & 1.901 & 1.939 & 1.969 & 1.995 \\
\hline Serpentinized harzburgite & $\sigma$ & 0.296 & 0.300 & 0.303 & 0.306 & 0.309 & 0.319 & 0.326 & 0.332 \\
\hline & $\kappa$ & 0.308 & 0.323 & 0.333 & 0.341 & 0.348 & 0.377 & 0.399 & 0.418 \\
\hline & $\mu$ & 0.146 & 0.149 & 0.151 & 0.152 & 0.153 & 0.155 & 0.157 & 0.158 \\
\hline $11 \mathrm{R}-1,128-131(\mathrm{~V})$ & $V_{\mu}$ & 2.027 & 2.013 & 2.012 & 2.015 & 2.021 & 2.049 & 2.072 & 2.093 \\
\hline Serpentinized harzburgite & $\sigma$ & 0.339 & 0.336 & 0.336 & 0.337 & 0.338 & 0.344 & 0.348 & 0.352 \\
\hline & $K$ & 0.426 & 0.432 & 0.437 & 0.443 & 0.448 & 0.469 & 0.485 & 0.500 \\
\hline & $\mu$ & 0.153 & 0.159 & 0.161 & 0.162 & 0.163 & 0.164 & 0.164 & 0.164 \\
\hline $12 \mathrm{R}-1,104-108$ & $V_{d} N$ & 2.055 & 2.068 & 2.075 & 2.081 & 2.086 & 2.100 & 2.106 & 2.111 \\
\hline Serpentinized harzburgite & $\sigma^{\theta / x}$ & 0.345 & 0.347 & 0.349 & 0.350 & 0.351 & 0.353 & 0.354 & 0.355 \\
\hline & $K$ & 0.574 & 0.593 & 0.605 & 0.614 & 0.622 & 0.642 & 0.652 & 0.659 \\
\hline & $\mu$ & 0.199 & 0.202 & 0.204 & 0.205 & 0.206 & 0.209 & 0.210 & 0.211 \\
\hline $13 \mathrm{R}-2,87-83(\mathrm{~V})$ & $V_{d} N$ & 2.118 & 2.019 & 1.996 & 1.993 & 1.998 & 2.024 & 2.040 & 2.051 \\
\hline Serpentinized harzburgite & & 0.357 & 0.338 & 0.332 & 0.332 & 0.333 & 0.338 & 0.342 & 0.344 \\
\hline & $K$ & 0.469 & 0.476 & 0.486 & 0.495 & 0.504 & 0.535 & 0.554 & 0.568 \\
\hline
\end{tabular}


Table 5 (continued).

\begin{tabular}{|c|c|c|c|c|c|c|c|c|c|c|c|}
\hline $\begin{array}{l}\text { Core, section, } \\
\text { interval (cm) } \\
\text { Lithology }\end{array}$ & Mode & $\begin{array}{c}20 \\
\mathrm{MPa}\end{array}$ & $\begin{array}{c}40 \\
\mathrm{MPa}\end{array}$ & $\begin{array}{c}60 \\
\mathrm{MPa}\end{array}$ & $\begin{array}{c}80 \\
\mathrm{MPa}\end{array}$ & $\begin{array}{l}100 \\
\mathrm{MPa}\end{array}$ & $\begin{array}{l}200 \\
\mathrm{MPa}\end{array}$ & $\begin{array}{c}300 \\
\mathrm{MPa}\end{array}$ & $\begin{array}{l}400 \\
\mathrm{MPa}\end{array}$ & $\begin{array}{l}500 \\
\mathrm{MPa}\end{array}$ & $\begin{array}{l}600 \\
\mathrm{MPa}\end{array}$ \\
\hline & $\mu$ & 0.149 & 0.174 & 0.183 & 0.188 & 0.189 & 0.194 & 0.196 & 0.198 & 0.199 & 0.200 \\
\hline $13 \mathrm{R}-2,84-87(\mathrm{H})$ & & 1.986 & 2.002 & 2.010 & 2.016 & 2.022 & 2.042 & 2.054 & 2.064 & 2.071 & 2.077 \\
\hline \multirow[t]{3}{*}{ Serpentinized harzburgite } & $\sigma$ & 0.330 & 0.334 & 0.336 & 0.337 & 0.338 & 0.342 & 0.345 & 0.347 & 0.348 & 0.349 \\
\hline & K & 0.466 & 0.496 & 0.512 & 0.524 & 0.534 & 0.564 & 0.583 & 0.596 & 0.607 & 0.616 \\
\hline & $\mu$ & 0.179 & 0.185 & 0.189 & 0.192 & 0.194 & 0.199 & 0.202 & 0.204 & 0.206 & 0.207 \\
\hline $14 \mathrm{R}-4,137-140$ & $V_{p}$ & 2.274 & 2.356 & 2.394 & 2.413 & 2.424 & 2.449 & 2.464 & 2.474 & 2.482 & 2.490 \\
\hline \multirow{3}{*}{ Serpentinized harzburgite } & $\sigma$ & 0.380 & 0.390 & 0.394 & 0.396 & 0.397 & 0.400 & 0.401 & 0.402 & 0.403 & 0.404 \\
\hline & $K$ & 0.470 & 0.529 & 0.560 & 0.578 & 0.590 & 0.617 & 0.633 & 0.644 & 0.653 & 0.660 \\
\hline & $\mu$ & 0.122 & 0.126 & 0.127 & 0.129 & 0.130 & 0.132 & 0.134 & 0.134 & 0.135 & 0.136 \\
\hline $15 \mathrm{R}-2,92-95(\mathrm{H})$ & & 2.290 & 2.205 & 2.162 & 2.141 & 2.132 & 2.135 & 2.147 & 2.156 & 2.164 & 2.170 \\
\hline \multirow[t]{3}{*}{ Serpentinized harzburgite } & $\sigma$ & 0.382 & 0.371 & 0.364 & 0.361 & 0.359 & 0.359 & 0.361 & 0.363 & 0.364 & 0.365 \\
\hline & $K$ & 0.464 & 0.475 & 0.482 & 0.489 & 0.495 & 0.523 & 0.541 & 0.555 & 0.567 & 0.576 \\
\hline & $\pi$ & 0.119 & 0.135 & 0.144 & 0.150 & 0.154 & 0.162 & 0.165 & 0.168 & 0.169 & 0.171 \\
\hline $15 \mathrm{R}-2,95-98(\mathrm{~V})$ & & 2.142 & 2.157 & 2.167 & 2.174 & 2.181 & 2.211 & 2.237 & 2.260 & 2.282 & 2.301 \\
\hline \multirow[t]{3}{*}{ Serpentinized harzburgite } & $\sigma$ & 0.361 & 0.363 & 0.365 & 0.366 & 0.367 & 0.371 & 0.375 & 0.378 & 0.381 & 0.384 \\
\hline & $K$ & 0.425 & 0.441 & 0.452 & 0.460 & 0.467 & 0.496 & 0.518 & 0.536 & 0.553 & 0.568 \\
\hline & $\mu$ & 0.131 & 0.133 & 0.134 & 0.136 & 0.137 & 0.140 & 0.141 & 0.142 & 0.143 & 0.143 \\
\hline $16 R-4,82-85$ & & 2.280 & 2.378 & 2.410 & 2.420 & 2.425 & 2.435 & 2.444 & 2.453 & 2.460 & 2.467 \\
\hline \multirow{3}{*}{ Serpentinized harzburgite } & $\sigma$ & 0.381 & 0.393 & 0.396 & 0.397 & 0.398 & 0.399 & 0.399 & 0.400 & 0.401 & 0.402 \\
\hline & $K$ & 0.390 & 0.449 & 0.474 & 0.486 & 0.493 & 0.513 & 0.525 & 0.534 & 0.541 & 0.546 \\
\hline & $\mu$ & 0.101 & 0.104 & 0.106 & 0.107 & 0.108 & 0.112 & 0.113 & 0.114 & 0.115 & 0.115 \\
\hline $17 \mathrm{R}-3,2-5(\mathrm{H})$ & & 2.048 & 2.069 & 2.080 & 2.089 & 2.096 & 2.121 & 2.139 & 2.151 & 2.160 & 2.168 \\
\hline \multirow{3}{*}{ Serpentinized harzburgite } & $\sigma^{\prime \prime}$ & 0.343 & 0.348 & 0.350 & 0.351 & 0.353 & 0.357 & 0.360 & 0.362 & 0.364 & 0.365 \\
\hline & $K$ & 0.412 & 0.437 & 0.451 & 0.462 & 0.470 & 0.497 & 0.513 & 0.526 & 0.535 & 0.543 \\
\hline & $\hat{\mu}$ & 0.144 & 0.148 & 0.151 & 0.152 & 0.154 & 0.157 & 0.158 & 0.160 & 0.160 & 0.161 \\
\hline $17 \mathrm{R}-3,5-8(\mathrm{~V})$ & & 2.301 & 2.319 & 2.331 & 2.342 & 2.351 & 2.381 & 2.402 & 2.418 & 2.433 & 2.446 \\
\hline \multirow[t]{3}{*}{ Serpentinized harzburgite } & $\sigma$ & 0.384 & 0.386 & 0.387 & 0.389 & 0.390 & 0.393 & 0.395 & 0.397 & 0.398 & 0.400 \\
\hline & K & 0.458 & 0.475 & 0.486 & 0.495 & 0.502 & 0.528 & 0.547 & 0.563 & 0.576 & 0.588 \\
\hline & $\ddot{\mu}$ & 0.116 & 0.117 & 0.118 & 0.119 & 0.120 & 0.122 & 0.123 & 0.125 & 0.126 & 0.127 \\
\hline $18 R-4,12-15$ & & 2.187 & 2.200 & 2.205 & 2.208 & 2.212 & 2.222 & 2.230 & 2.237 & 2.243 & 2.249 \\
\hline \multirow[t]{3}{*}{ Serpentinized harzburgite } & $\sigma^{\prime}$ & 0.368 & 0.370 & 0.371 & 0.371 & 0.372 & 0.373 & 0.374 & 0.375 & 0.376 & 0.377 \\
\hline & $K$ & 0.604 & 0.621 & 0.630 & 0.635 & 0.640 & 0.654 & 0.665 & 0.673 & 0.680 & 0.686 \\
\hline & $\mu$ & 0.175 & 0.177 & 0.178 & 0.179 & 0.180 & 0.182 & 0.183 & 0.183 & 0.184 & 0.184 \\
\hline $19 \mathrm{R}-1,18-21$ & & 2.058 & 2.068 & 2.068 & 2.067 & 2.068 & 2.076 & 2.083 & 2.089 & 2.093 & 2.097 \\
\hline \multirow{3}{*}{ Serpentinized harzburgite } & $\sigma$ & 0.345 & 0.347 & 0.347 & 0.347 & 0.347 & 0.349 & 0.350 & 0.351 & 0.352 & 0.353 \\
\hline & $K$ & 0.511 & 0.543 & 0.556 & 0.564 & 0.569 & 0.586 & 0.597 & 0.605 & 0.611 & 0.616 \\
\hline & $\mu$ & 0.176 & 0.184 & 0.189 & 0.192 & 0.193 & 0.197 & 0.199 & 0.200 & 0.200 & 0.201 \\
\hline 20R-5, 95-99(V) & $v_{p}$ & 2.044 & 2.033 & 2.031 & 2.032 & 2.034 & 2.049 & 2.064 & 2.077 & 2.088 & 2.098 \\
\hline \multirow[t]{3}{*}{ Serpentinized harzburgite } & p & 0.343 & 0.340 & 0.340 & 0.340 & 0.341 & 0.344 & 0.347 & 0.349 & 0.351 & 0.353 \\
\hline & K & 0.463 & 0.472 & 0.479 & 0.485 & 0.491 & 0.515 & 0.5 & 0.5 & & 0.580 \\
\hline & 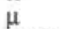 & 0.163 & 0.169 & 0.172 & 0.174 & 0.175 & 0.180 & 0.183 & 0.185 & 0.187 & 0.189 \\
\hline $20 \mathrm{R}-5,98-101(\mathrm{H})$ & & 2.204 & 2.290 & 2.324 & 2.340 & 2.349 & 2.368 & 2.378 & 2.384 & 2.389 & 2.393 \\
\hline \multirow{3}{*}{ Serpentinized harzburgite } & , & 0.370 & 0.382 & 0.386 & 0.388 & 0.389 & 0.392 & 0.393 & 0.393 & 0.394 & 0.394 \\
\hline & K & 0.445 & 0.505 & 0.533 & 0.548 & 0.557 & 0.582 & 0.597 & 0.6 & & 0.623 \\
\hline & & 0.126 & 0.129 & 0.131 & 0.132 & 0.133 & 0.136 & 0.138 & 0.140 & & 0.142 \\
\hline & & 2.070 & 2.099 & 2.121 & 2.139 & 2.153 & 2.194 & 2.212 & 2.224 & 2.232 & 2.239 \\
\hline \multirow{3}{*}{ Serpentinized harzburgite } & $\sigma$ & 0.348 & 0.353 & 0.357 & 0.360 & 0.362 & 0.369 & 0.372 & 0.373 & 0.374 & 0.375 \\
\hline & $K$ & 0.410 & 0.446 & 0.471 & 0.489 & 0.503 & 0.540 & 0.5 & 0.5 & 0.5 & 0.580 \\
\hline & $\mu$ & 0.139 & 0.145 & 0.149 & 0.151 & 0.152 & 0.155 & 0.156 & 0.157 & 0.157 & 0.158 \\
\hline & 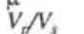 & 1.876 & 1.878 & 1.881 & 1.885 & 1.889 & 1.904 & 1.912 & 1.917 & 1.919 & 1.920 \\
\hline Serpentinized harzburgite & $\sigma$ & 0.302 & 0.302 & 0.303 & 0.304 & 0.305 & 0.310 & 0.312 & 0.313 & 0.313 & 0.314 \\
\hline & $K$ & 0.56 & 0.58 & 0.599 & 0.611 & 0.621 & 0.654 & 0.671 & 0.682 & 0.689 & 0.694 \\
\hline & & 0.2 & 0.2 & 0.272 & 0.275 & 0.2 & 0.2 & 0.2 & 0.2 & 0.294 & 0.295 \\
\hline $22 \mathrm{R}-4,42-45(\mathrm{~V})$ & $v$ & 2.247 & 2.284 & 2.308 & 2.328 & 2.343 & 2.398 & 2.428 & 2.450 & 2.466 & 2.479 \\
\hline Serpentinized harzburgite & $\sigma$ & 0.377 & 0.381 & 0.384 & 0.387 & 0.389 & 0.395 & 0.398 & 0.400 & 0.402 & 0.403 \\
\hline & 0 & 0.400 & 0.427 & 0.444 & 0.457 & 0.469 & 0.508 & 0.533 & 0.551 & 0.565 & 0.577 \\
\hline & & 0.108 & 0.110 & 0.111 & 0.112 & 0.113 & 0.115 & 0.117 & 0.118 & 0.119 & 0.120 \\
\hline $22 \mathrm{R}-4,47-50(\mathrm{H})$ & $V_{g} / N_{s}$ & 2.004 & 2.010 & 2.011 & 2.012 & 2.012 & 2.023 & 2.034 & 2.042 & 2.048 & 2.053 \\
\hline Serpentinized harzburgite & $\sigma$ & 0.334 & 0.335 & 0.336 & 0.336 & 0.336 & 0.338 & 0.341 & 0.342 & 0.343 & 0.344 \\
\hline & $K$ & 0.583 & 0.635 & 0.665 & 0.683 & 0.696 & 0.729 & 0.746 & 0.759 & 0.768 & 0.776 \\
\hline & $\mu$ & 0.217 & 0.235 & 0.245 & 0.252 & 0.256 & 0.264 & 0.266 & 0.268 & 0.269 & 0.270 \\
\hline
\end{tabular}

Notes: $(\mathrm{H})=$ horizontally oriented minicore (relative to core axis); $(\mathrm{V})=$ vertically oriented minicore. Units for $\sigma$ and $\mu$ are $\mathrm{MPa} \times 10^{-2}$.

to produce a section of any considerable length. Irrespective of lithology, multiple reentries are a necessity of deep drilling into oceanic crust. The rocks are undoubtedly drillable, and we should continue to develop programs and strategies to drill sites in these settings. Only through future drilling programs, with deeper penetration and more complete recovery, can we develop a full understanding of the petrologic, tectonic, and geophysical structure of the oceanic crust.

\section{ACKNOWLEDGMENTS}

The authors would like to thank Dr. Carolyn Mutter for making the shipboard physical properties measurements during Leg 153. This research was supported by USSSP grant $153-20850$ B to D.J. Miller, and by Office of Naval Research contract N-00014-89-J1209 to N.I. Christensen. Lewis Scott and Jian Ping Xu are thanked for making the velocity measurements. This manuscript benefited from critical reviews by M.H. Salisbury, P.J. Fox, and J. A. Karson.

\section{REFERENCES}

Aslanyan, A.T., Volarovic, M.P., Levykin, A.I., Beguni, A.T., Artunyan, A.V., and Skvortsov, L.S., 1976. Elastic wave velocities in Armenian basic and ultrabasic rocks at high pressures. Phys. Solid Earth, 12:96102.

Birch, F., 1960. The velocity of compressional waves in rocks to 10 kilobars, 1. J. Geophys. Res., 65:1083-1102.

, 1961. The velocity of compressional waves in rocks to 10 kilobars, 2. J. Geophys. Res., 66:2199-2224.

Brown, J.R., and Karson, J.A., 1988. Variations in axial processes on the Mid-Atlantic Ridge: the median valley of the MARK area. Mar. Geophys. Res., 10:109-138.

Cannat, M., and Casey, J.F., 1995. An ultramafic lift at the Mid-Atlantic Ridge: successive stages of magmatism in serpentinized peridotites from 
the $15^{\circ} \mathrm{N}$ region. In Vissers, R.L.M., and Nicolas, A. (Eds.), Mantle and Lower Crust Exposed in Oceanic Ridges and Ophiolites: Dordrecht (Kluwer), 5-34.

Cannat, M., Karson, J.A., Miller, D.J., et al., 1995. Proc. ODP, Init. Repts., 153: College Station, TX (Ocean Drilling Program).

Cannat, M., Mével, C., Maia, M., Deplus, C., Durand, C., Gente, P., Agrinier, P., Belarouchi, A., Dubuisson, G., et al., 1995. Thin crust, ultramafic exposures, and rugged faulting patterns at the Mid-Atlantic Ridge $\left(22^{\circ}-\right.$ $\left.24^{\circ} \mathrm{N}\right)$. Geology, 23:49-52.

Casey, J.F., Dewey, J.F., Fox, P.J., Karson, J.A., and Rosencrantz, E., 1981. Heterogeneous nature of oceanic crust and upper mantle: a perspective from the Bay of Islands Ophiolite Complex. In Emiliani, C. (Ed.), The Sea (Vol. 7) The Oceanic Lithosphere: New York (Wiley), 305-338.

Christensen, N.I., 1965. Compressional-wave velocities in metamorphic rocks at pressures to 10 kilobars. J. Geophys. Res., 70:6147-6164.

, 1966. Elasticity of ultrabasic rocks. J. Geophys. Res., 71:59215931.

1972. The abundance of serpentinites in the oceanic crust. $J$. Geol., 80:709-719.

, 1974. The petrologic nature of the lower oceanic crust and upper mantle. In Kristjansson, L. (Ed.), Geodynamics of Iceland and the North Atlantic Area. NATO ASI Ser., Ser. C:, 11:165-176.

1978. Ophiolites, seismic velocities and oceanic crustal structure. Tectonophysics, 47:131-157.

1982. Seismic velocities. In Carmichael, R.S. (Ed.), Handbook of Physical Properties of Rocks: Boca Raton, FL (CRC Press), 2:1-228.

, 1985. Measurements of dynamic properties of rocks at elevated temperatures and pressures. In Pincus, H.J., and Hoskins, E.R. (Eds.), Measurements of Rock Properties at Elevated Pressures and Temperatures: Philadelphia (Am. Soc. for Testing and Materials), ASTM STP 869:93-107.

Christensen, N.I., and Salisbury, M.H., 1972. Sea floor spreading, progressive alteration of layer 2 basalts, and associated changes in seismic velocities. Earth Planet. Sci. Lett., 15:367-375.

Coleman, R.G., 1977. Ophiolites: Ancient Oceanic Lithosphere: New York (Springer-Verlag).

Detrick, R.S., Fox, P.J., Schulz, N., Pockalny, R., Knog, L., Mayer, L., and Ryan, W.B.F., 1988. Geologic and tectonic setting of the mark area. In Detrick, R., Honnorez, J., et al., Proc. ODP, Init. Repts., 106/109: College Station, TX (Ocean Drilling Program), 15-22.

Elo, S., and Korja, A., 1993. Geophysical interpretation of the crustal and upper mantle structure in the Wiborg rapakivi granite area, southeastern Finland. Precambrian Res., 64:273-288.

Fox, P.J., Schreiber, E., and Peterson, J.J., 1973. The geology of the oceanic crust: compressional wave velocities of oceanic rocks. J. Geophys. Res., 78:5155-5172.

Fox, P.J., and Stroup, J., 1981. The plutonic foundation of the oceanic crust. In Emiliani, C. (Ed.), The Sea (Vol. 7): The Oceanic Lithosphere: New York (Wiley), 119-218.

Hill, R., 1952. The elastic behavior of a crystalline aggregate. Proc. Phys. Soc. London, Sect. A, 65:349-354.

Hyndman, R.D., and Drury, M.J., 1976. The physical properties of oceanic basement rocks from deep drilling on the Mid-Atlantic Ridge. J. Geophys. Res., 81:4042-4052.

Iturrino, G.J., Christensen, N.I., Kirby, S., and Salisbury, M.H., 1991. Seismic velocities and elastic properties of oceanic gabbroic rocks from Hole 735B. In Von Herzen, R.P., Robinson, P.T., et al., Proc. ODP, Sci. Results, 118: College Station, TX (Ocean Drilling Program), 227-244.

Iturrino G.J., Miller, D.J., and Christensen, N.I., 1996. Velocity behavior of lower crustal and upper mantle rocks from a fast-spreading ridge at Hess Deep. In Mével, C., Gillis, K.M., Allan, J.F., and Meyer, P.S. (Eds.), Proc. ODP, Sci. Results, 147: College Station, TX (Ocean Drilling Program), 417-440.

Karson, J.A., and Dick, H.J.B., 1983. Tectonics of ridge-transform intersections at the Kane Fracture Zone. Mar. Geophys. Res., 6:51-98.

Karson, J.A., and Fox, P.J., 1986. Geological and geophysical investigation of the Mid-Cayman spreading centre; seismic velocity measurements and implications for the constitution of layer 3. Geophys. J. R. Astron. Soc., 85:389-411.

Karson, J.A., Fox, P.J., Sloan, H., Crane, K.T., Kidd, W.S.F., Bonatti, E., Stroup, J.B., Fornari, D.J., Elthon, D., Hamlyn, P., Casey, J.F., Gallo, D.G., Needham, D., and Sartori, R., 1984. The geology of the Oceanographer Transform: the ridge-transform intersection. Mar. Geophys. Res., 6:109-141.

Karson, J.A., Thompson, G., Humphris, S.E., Edmond, J.M., Bryan, W.B., Brown, J.R., Winters, A.T., Pockalny, R.A., Casey, J.F., Campbell, A.C., Klinkhammer, G., Palmer, M.R., Kinzler, R.J., and Sulanowska, M.M., 1987. Along-axis variations in seafloor spreading in the MARK area. Nature, 328:681-685.

Kern, H., and Tubia, J.M., 1993. Pressure and temperature dependence of Pand S-wave velocities, seismic anisotropy and density of sheared rock from the Sierra Alpujata (Ronda peridotites, Southern Spain). Earth Planet. Sci. Lett., 119:191-205.

Kroenke, L.W., Manghnani, M.H., Rai., C.S., Fryer, P., and Ramananantoandro, R., 1976. Elastic properties of selected ophiolitic rocks from Papua, New Guinea: nature and composition of oceanic lower crust and upper mantle. In Sutton, G.H., Manghnani, M.H., and Moberly, R. (Eds.), The Geophysics of the Pacific Ocean Basin and its Margins. Am. Geophys. Union, 19:407-421.

Mével, C., Cannat, M., Gente, P., Marion, E., Auzende, J.-M., and Karson, J.A., 1991. Emplacement of deep crustal and mantle rocks on the west median valley wall of the MARK area (MAR $23^{\circ} \mathrm{N}$ ). Tectonophysics, 190:31-53.

Miller, D.J., Iturrino G.J., and Christensen, N.I., 1996. Geochemical and petrological constraints on velocity behavior of lower crustal and upper mantle rocks from the fast-spreading ridge at Hess Deep. In Mével, C., Gillis, K.M., Allan, J.F., and Meyer, P.S. (Eds.), Proc. ODP, Sci. Results, 147: College Station, TX (Ocean Drilling Program), 477-490.

Moores, E.M., and Vine, F.J., 1971. The Troodos Massif, Cyprus and other ophiolites as oceanic crust: evaluation and implications. Philos. Trans. $R$. Soc. London A, 268:433-466.

Nicolas, A., 1989. Structure of Ophiolites and Dynamics of the Oceanic Lithosphere: Dordrecht (Kluwer).

O'Connell, R.J., and Budianski, B., 1974. Seismic velocities in dry and saturated cracked solids. J. Geophys. Res., 79:5412-5426.

Phillips, J.D., Thompson, G., Von Herzen, R.P., and Bowen, V.T., 1969. MidAtlantic Ridge near $43^{\circ}$ latitude. J. Geophys. Res., 74:3069-3081.

Ramana, Y.V., and Rao, M.V.M.S., 1974. Compressional velocities in ultramafic rocks of India at pressures to five kilobars. Geophys. J. R. Astron. Soc., 37:207-212.

Reuss, A., 1929. Berechnung der Fliessgrenze von Mischkristallen auf Grund der Plastizitatsbedingung fur Einkristalle. Z. Agnew. Math. Mech., 9:49-54.

Schreiber, E., and Fox, P.J., 1977. Density and P-wave velocity of rocks from the FAMOUS region and their implication to the structure of the oceanic crust. Geol. Soc. Am. Bull., 88:600-608.

Shipboard Scientific Party, 1988. Site 670. In Detrick, R., Honnorez, J., Bryan, W.B., Juteau, T., et al., Proc. ODP, Init. Repts., 109: College Station, TX (Ocean Drilling Program), 203-238.

Stroup, J.B., and Fox, P.J., 1981. Geologic investigations in the Cayman Trough: evidence for thin oceanic crust along the Mid-Cayman Rise. $J$. Geol., 89:395-420.

Tatham, R.H., 1982. $V_{p} / V_{s}$ and lithology. Geophysics, 47:336-344.

Voigt, W., 1928. Lehrbuch der Kristallphysik: Leipzig (B.G. Teulner).

Wilkens, R.H., Simmons, G., and Caruso, L., 1984. The ratio $V_{f} / V_{s}$ as a discriminant of composition for siliceous limestones. Geophysics, 49:18501860.

Date of initial receipt: 28 July 1995

Date of acceptance: 19 December 1995

Ms 153SR-043 
Table 6. Elastic constants for samples from Hole 923A.

\begin{tabular}{|c|c|c|c|c|c|c|c|c|c|}
\hline $\begin{array}{l}\text { Core section, } \\
\text { interval }(\mathrm{cm}) \\
\text { Lithology }\end{array}$ & Mode & $\begin{array}{c}20 \\
\mathrm{MPa}\end{array}$ & $\begin{array}{c}40 \\
\mathrm{MPa}\end{array}$ & $\begin{array}{c}60 \\
\mathrm{MPa}\end{array}$ & $\begin{array}{c}80 \\
\mathrm{MPa}\end{array}$ & $\begin{array}{r}100 \\
\mathrm{MPa}\end{array}$ & $\begin{array}{l}200 \\
\mathrm{MPa}\end{array}$ & $\begin{array}{l}300 \\
\mathrm{MPa}\end{array}$ & $\begin{array}{l}400 \\
\mathrm{MPa}\end{array}$ \\
\hline 153-923A- & & & & & & & & & \\
\hline $2 R-2,2-5$ & $V_{t} J V_{s}$ & 1.822 & 1.825 & 1.825 & 1.824 & 1.822 & 1.817 & 1.814 & 1.812 \\
\hline Olivine gabbro & & 0.285 & 0.285 & 0.285 & 0.285 & 0.285 & 0.283 & 0.282 & 0.281 \\
\hline & $\mathrm{K}$ & 0.694 & 0.718 & 0.731 & 0.739 & 0.745 & 0.759 & 0.767 & 0.773 \\
\hline & $\mu$ & 0.349 & 0.360 & 0.366 & 0.371 & 0.375 & 0.386 & 0.392 & 0.396 \\
\hline 2R-2, 89-92 & $V_{\mu} J$ & 1.762 & 1.773 & 1.777 & 1.777 & 1.778 & 1.783 & 1.788 & 1.791 \\
\hline Gabbro & $\sigma$ & 0.262 & 0.267 & 0.268 & 0.268 & 0.269 & 0.271 & 0.272 & 0.273 \\
\hline & K & 0.752 & 0.801 & 0.824 & 0.835 & 0.842 & 0.862 & 0.875 & 0.884 \\
\hline & $\mu$ & 0.425 & 0.442 & 0.452 & 0.457 & 0.461 & 0.467 & 0.470 & 0.472 \\
\hline $2 \mathrm{R}-2,92-96$ & $V_{p}$ & 1.786 & 1.792 & 1.795 & 1.797 & 1.799 & 1.807 & 1.812 & 1.816 \\
\hline Olivine gabbro & $\sigma$ & 0.272 & 0.274 & 0.275 & 0.276 & 0.276 & 0.279 & 0.281 & 0.282 \\
\hline & $\mathrm{K}$ & 0.757 & 0.790 & 0.807 & 0.819 & 0.827 & 0.851 & 0.865 & 0.875 \\
\hline & $\mu$ & 0.408 & 0.420 & 0.428 & 0.432 & 0.434 & 0.441 & 0.444 & 0.446 \\
\hline $3 R-1,95-98$ & $V_{\nu}$ & 1.786 & 1.812 & 1.818 & 1.818 & 1.817 & 1.819 & 1.824 & 1.828 \\
\hline Olivine gabbro & $\sigma^{p}$ & 0.272 & 0.281 & 0.283 & 0.283 & 0.283 & 0.284 & 0.285 & 0.286 \\
\hline & $\mathrm{K}$ & 0.681 & 0.749 & 0.778 & 0.791 & 0.799 & 0.821 & 0.835 & 0.845 \\
\hline & $\mu$ & 0.367 & 0.384 & 0.395 & 0.401 & 0.406 & 0.415 & 0.419 & 0.421 \\
\hline $3 R-2,34-38$ & $V_{p}$ & 1.869 & 1.871 & 1.866 & 1.860 & 1.855 & 1.847 & 1.851 & 1.855 \\
\hline Olivine gabbro & $\sigma$ & 0.299 & 0.300 & 0.299 & 0.297 & 0.295 & 0.293 & 0.294 & 0.295 \\
\hline & K & 0.749 & 0.800 & 0.824 & 0.836 & 0.843 & 0.862 & 0.876 & 0.887 \\
\hline & $\mu$ & 0.347 & 0.369 & 0.383 & 0.393 & 0.400 & 0.415 & 0.419 & 0.421 \\
\hline $4 \mathrm{R}-1,52-56$ & & 1.795 & 1.814 & 1.816 & 1.811 & 1.805 & 1.786 & 1.782 & 1.782 \\
\hline Olivine gabbro & $\sigma$ & 0.275 & 0.282 & 0.282 & 0.281 & 0.279 & 0.272 & 0.270 & 0.270 \\
\hline & K & 0.726 & 0.786 & 0.812 & 0.823 & 0.828 & 0.838 & 0.848 & 0.858 \\
\hline & $\mu$ & 0.385 & 0.401 & 0.413 & 0.423 & 0.430 & 0.452 & 0.461 & 0.466 \\
\hline $4 \mathrm{R}-1,65-70$ & $V_{p}$ & 1.835 & 1.828 & 1.825 & 1.823 & 1.823 & 1.827 & 1.831 & 1.834 \\
\hline Olivine gabbro & $\sigma$ & 0.289 & 0.286 & 0.285 & 0.285 & 0.285 & 0.286 & 0.288 & 0.289 \\
\hline & K & 0.784 & 0.816 & 0.833 & 0.844 & 0.853 & 0.874 & 0.886 & 0.895 \\
\hline & $\mu$ & 0.386 & 0.406 & 0.417 & 0.424 & 0.428 & 0.436 & 0.439 & 0.440 \\
\hline SR-2, 114-117 & & 1.812 & 1.819 & 1.824 & 1.828 & 1.831 & 1.836 & 1.835 & 1.834 \\
\hline Olivine gabbro & $\sigma$ & 0.281 & 0.283 & 0.285 & 0.287 & 0.288 & 0.289 & 0.289 & 0.288 \\
\hline & $\mathrm{K}$ & 0.796 & 0.820 & 0.837 & 0.849 & 0.858 & 0.880 & 0.888 & 0.893 \\
\hline & $\mu$ & 0.408 & 0.416 & 0.420 & 0.422 & 0.425 & 0.432 & 0.437 & 0.440 \\
\hline $6 \mathrm{R}-1,106-110$ & & 1.816 & 1.820 & 1.822 & 1.823 & 1.823 & 1.825 & 1.827 & 1.829 \\
\hline Olivine gabbro & & 0.282 & 0.284 & 0.284 & 0.285 & 0.285 & 0.286 & 0.286 & 0.287 \\
\hline & $\mathrm{K}$ & 0.823 & 0.847 & 0.861 & 0.871 & 0.877 & 0.896 & 0.905 & 0.912 \\
\hline & $\mu$ & 0.419 & 0.428 & 0.434 & 0.438 & 0.441 & 0.448 & 0.451 & 0.453 \\
\hline $7 \mathrm{R}-1,81-84$ & $V_{p} J$ & 1.864 & 1.847 & 1.837 & 1.830 & 1.827 & 1.825 & 1.828 & 1.831 \\
\hline Olivine gabbro & $\sigma$ & 0.298 & 0.293 & 0.289 & 0.287 & 0.286 & 0.285 & 0.286 & 0.287 \\
\hline & K & 0.897 & 0.905 & 0.908 & 0.911 & 0.914 & 0.929 & 0.941 & 0.952 \\
\hline & $\mu$ & 0.419 & 0.435 & 0.445 & 0.452 & 0.456 & 0.466 & 0.469 & 0.471 \\
\hline $8 R-1,107-110$ & $V_{p j}$ & 1.900 & 1.896 & 1.893 & 1.889 & 1.887 & 1.883 & 1.883 & 1.883 \\
\hline Troctolite & $\sigma$ & 0.309 & 0.307 & 0.306 & 0.305 & 0.305 & 0.304 & 0.304 & 0.304 \\
\hline & $\mathrm{K}$ & 0.816 & 0.836 & 0.846 & 0.852 & 0.856 & 0.867 & 0.874 & 0.879 \\
\hline & $\mu$ & 0.358 & 0.369 & 0.376 & 0.381 & 0.384 & 0.392 & 0.395 & 0.397 \\
\hline $9 \mathrm{R}-1,130-133$ & & 1.868 & 1.852 & 1.843 & 1.838 & 1.836 & 1.837 & 1.842 & 1.845 \\
\hline Olivine gabbro & & 0.299 & 0.294 & 0.291 & 0.290 & 0.289 & 0.290 & 0.291 & 0.292 \\
\hline & $\mathrm{K}$ & 0.882 & 0.892 & 0.898 & 0.903 & 0.908 & 0.928 & 0.942 & 0.952 \\
\hline & $\mu$ & 0.409 & 0.425 & 0.435 & 0.441 & 0.445 & 0.454 & 0.458 & 0.460 \\
\hline $9 \mathrm{R}-2,70-73$ & & 1.834 & 1.858 & 1.864 & 1.864 & 1.864 & 1.865 & 1.867 & 1.869 \\
\hline Olivine gabbro & & 0.288 & 0.296 & 0.298 & 0.298 & 0.298 & 0.298 & 0.299 & 0.299 \\
\hline & $\mathrm{K}$ & 0.778 & 0.832 & 0.853 & 0.862 & 0.868 & 0.886 & 0.898 & 0.906 \\
\hline & $\mu$ & 0.383 & 0.393 & 0.398 & 0.403 & 0.406 & 0.413 & 0.417 & 0.419 \\
\hline I0R-1, $40-44$ & & 1.822 & 1.815 & 1.811 & 1.811 & 1.811 & 1.812 & 1.813 & 1.813 \\
\hline Olivine gabbro & & 0.285 & 0.282 & 0.281 & 0.281 & 0.281 & 0.281 & 0.281 & 0.281 \\
\hline & $\mathrm{K}$ & 0.852 & 0.872 & 0.884 & 0.893 & 0.898 & 0.915 & 0.924 & 0.931 \\
\hline & $\mu$ & 0.429 & 0.445 & 0.454 & 0.459 & 0.462 & 0.470 & 0.474 & 0.476 \\
\hline $10 \mathrm{R}-1,106-109$ & & 1.786 & 1.807 & 1.815 & 1.818 & 1.817 & 1.807 & 1.801 & 1.799 \\
\hline Olivine gabbro & & 0.272 & 0.279 & 0.282 & 0.283 & 0.283 & 0.279 & 0.277 & 0.276 \\
\hline & $\mathrm{K}$ & 0.717 & 0.774 & 0.804 & 0.820 & 0.829 & 0.841 & 0.845 & 0.849 \\
\hline & $\mu$ & 0.386 & 0.400 & 0.410 & 0.416 & 0.422 & 0.435 & 0.442 & 0.446 \\
\hline I0R-3, 44-47 & & 1.835 & 1.834 & 1.835 & 1.838 & 1.840 & 1.845 & 1.843 & 1.840 \\
\hline Olivine gabbro & & 0.289 & 0.288 & 0.289 & 0.290 & 0.290 & 0.292 & 0.291 & 0.291 \\
\hline & K & 0.770 & 0.797 & 0.817 & 0.834 & 0.846 & 0.880 & 0.890 & 0.895 \\
\hline & $\mu$ & 0.379 & 0.393 & 0.401 & 0.408 & 0.412 & 0.425 & 0.431 & 0.436 \\
\hline $11 \mathrm{R}-1,55-58$ & & 1.801 & 1.775 & 1.766 & 1.762 & 1.761 & 1.757 & 1.754 & 1.752 \\
\hline Olivine gabbro & & 0.277 & 0.267 & 0.264 & 0.262 & 0.262 & 0.260 & 0.259 & 0.258 \\
\hline & $\mathrm{K}$ & 0.841 & 0.862 & 0.877 & 0.888 & 0.896 & 0.915 & 0.923 & 0.930 \\
\hline & $\mu$ & 0.440 & 0.474 & 0.492 & 0.501 & 0.507 & 0.522 & 0.530 & 0.536 \\
\hline 11R-1, 69-72 & & 1.811 & 1.822 & 1.826 & 1.825 & 1.825 & 1.823 & 1.823 & 1.824 \\
\hline Olivine gabbro & $\sigma$ & 0.281 & 0.285 & 0.286 & 0.286 & 0.286 & 0.285 & 0.285 & 0.285 \\
\hline & $\mathrm{K}$ & 0.822 & 0.857 & 0.873 & 0.881 & 0.886 & 0.897 & 0.904 & 0.909 \\
\hline & $\mu$ & 0.422 & 0.431 & 0.437 & 0.441 & 0.444 & 0.451 & 0.454 & 0.456 \\
\hline $11 R-2,56-61$ & & 1.829 & 1.839 & 1.842 & 1.842 & 1.841 & 1.836 & 1.836 & 1.837 \\
\hline Gabbro & & 0.287 & 0.290 & 0.291 & 0.291 & 0.291 & 0.289 & 0.289 & 0.289 \\
\hline & K & 0.832 & 0.879 & 0.904 & 0.919 & 0.928 & 0.949 & 0.961 & 0.970 \\
\hline & $\mu$ & 0.413 & 0.429 & 0.439 & 0.446 & 0.452 & 0.466 & 0.472 & 0.475 \\
\hline $12 \mathrm{R}-1,120-124$ & & 1.898 & 1.879 & 1.865 & 1.854 & 1.846 & 1.826 & 1.819 & 1.769 \\
\hline Troctolite & & 0.308 & 0.302 & 0.298 & 0.295 & 0.292 & 0.286 & 0.284 & 0.265 \\
\hline & K & 0.716 & 0.751 & 0.771 & 0.783 & 0.790 & 0.805 & 0.812 & 0.748 \\
\hline & $\mu$ & 0.316 & 0.342 & 0.359 & 0.372 & 0.381 & 0.402 & 0.411 & 0.416 \\
\hline $12 \mathrm{R}-1,126-129$ & & 1.933 & 1.941 & 1.941 & 1.940 & 1.939 & 1.940 & 1.942 & 1.944 \\
\hline Troctolite & $\sigma$ & 0.317 & 0.319 & 0.319 & 0.319 & 0.319 & 0.319 & 0.320 & 0.320 \\
\hline & K & 0.787 & 0.827 & 0.846 & 0.857 & 0.864 & 0.885 & 0.897 & 0.907 \\
\hline & $\mu$ & 0.327 & 0.340 & 0.348 & 0.352 & 0.356 & 0.364 & 0.368 & 0.371 \\
\hline $12 R-2,41-44$ & $V, f V_{x}$ & 1.776 & 1.777 & 1.775 & 1.773 & 1.772 & 1.769 & 1.771 & 1.773 \\
\hline Olivine gabbro & & 0.268 & 0.268 & 0.267 & 0.267 & 0.266 & 0.265 & 0.266 & 0.267 \\
\hline & K & 0.778 & 0.800 & 0.810 & 0.817 & 0.822 & 0.837 & 0.848 & 0.856 \\
\hline
\end{tabular}


Table 6 (continued).

\begin{tabular}{|c|c|c|c|c|c|c|c|c|c|c|c|}
\hline $\begin{array}{c}\text { Core section, } \\
\text { interval }(\mathrm{cm}) \\
\text { Lithology }\end{array}$ & Mode & $\begin{array}{c}20 \\
\mathrm{MPa}\end{array}$ & $\begin{array}{c}40 \\
\mathrm{MPa}\end{array}$ & $\begin{array}{c}60 \\
\mathrm{MPa}\end{array}$ & $\begin{array}{c}80 \\
\mathrm{MPa}\end{array}$ & $\begin{array}{c}100 \\
\mathrm{MPa}\end{array}$ & $\begin{array}{l}200 \\
\mathrm{MPa}\end{array}$ & $\begin{array}{c}300 \\
\mathrm{MPa}\end{array}$ & $\begin{array}{c}400 \\
\mathrm{MPa}\end{array}$ & $\begin{array}{c}500 \\
\mathrm{MPa}\end{array}$ & $\begin{array}{r}600 \\
\mathrm{MPa}\end{array}$ \\
\hline & $\mu$ & 0.428 & 0.438 & 0.446 & 0.451 & 0.455 & 0.466 & 0.470 & 0.472 & 0.474 & 0.475 \\
\hline $13 \mathrm{R}-1,114-117$ & $V_{p}$ & 1.820 & 1.814 & 1.810 & 1.810 & 1.810 & 1.814 & 1,817 & 1.819 & 1.822 & 1.823 \\
\hline \multirow[t]{3}{*}{ Olivine gabbro } & $\sigma$ & 0.284 & 0.282 & 0.280 & 0.280 & 0.280 & 0.282 & 0.283 & 0.284 & 0.284 & 0.285 \\
\hline & $\mathrm{K}$ & 0.841 & 0.852 & 0.859 & 0.865 & 0.870 & 0.888 & 0.899 & 0.907 & 0.914 & 0.919 \\
\hline & $\mu$ & 0.425 & 0.436 & 0.442 & 0.446 & 0.448 & 0.454 & 0.457 & 0.459 & 0.460 & 0.462 \\
\hline $13 R-3,50-53$ & $V_{p}$ & 1.786 & 1.804 & 1.804 & 1.800 & 1.796 & 1.790 & 1.790 & 1.791 & 1.792 & 1.793 \\
\hline \multirow[t]{3}{*}{ Olivine gabbro } & $\sigma$ & 0.272 & 0.278 & 0.278 & 0.277 & 0.275 & 0.273 & 0.273 & 0.274 & 0.274 & 0.274 \\
\hline & $\mathrm{K}$ & 0.692 & 0.771 & 0.804 & 0.819 & 0.826 & 0.845 & 0.858 & 0.867 & 0.874 & 0.881 \\
\hline & $\mu$ & 0.372 & 0.401 & 0.419 & 0.429 & 0.437 & 0.452 & 0.458 & 0.462 & 0.466 & 0.468 \\
\hline $14 \mathrm{R}-1,55-58$ & $V_{p}$ & 1.806 & 1.803 & 1.820 & 1.819 & 1.818 & 1.816 & 1.818 & 1.819 & 1.821 & 1.822 \\
\hline \multirow[t]{3}{*}{ Troctolite } & $\sigma$ & 0.279 & 0.278 & 0.284 & 0.284 & 0.283 & 0.282 & 0.283 & 0.283 & 0.284 & 0.284 \\
\hline & $\mathrm{K}$ & 0.701 & 0.717 & 0.753 & 0.762 & 0.767 & 0.781 & 0.791 & 0.797 & 0.803 & 0.808 \\
\hline & $\mu$ & 0.363 & 0.374 & 0.381 & 0.386 & 0.389 & 0.398 & 0.401 & 0.404 & 0.405 & 0.407 \\
\hline $14 \mathrm{R}-2,6-9$ & & 1.857 & 1.860 & 1.863 & 1.865 & 1.868 & 1.869 & 1.868 & 1.866 & 1.865 & 1.864 \\
\hline \multirow[t]{3}{*}{ Olivine gabbro } & $\sigma$ & 0.296 & 0.297 & 0.298 & 0.298 & 0.299 & 0.300 & 0.299 & 0.299 & 0.298 & 0.298 \\
\hline & $\mathrm{K}$ & 0.741 & 0.774 & 0.796 & 0.811 & 0.823 & 0.852 & 0.863 & 0.870 & 0.875 & 0.879 \\
\hline & $\mu$ & 0.351 & 0.364 & 0.372 & 0.378 & 0.382 & 0.394 & 0.400 & 0.405 & 0.408 & 0.411 \\
\hline $15 R-2,88-91$ & $V_{p}$ & 1.833 & 1.829 & 1.829 & 1.830 & 1.832 & 1.836 & 1.836 & 1.836 & 1.835 & 1.834 \\
\hline \multirow{3}{*}{ Troctolite } & $\sigma$ & 0.288 & 0.287 & 0.287 & 0.287 & 0.288 & 0.289 & 0.289 & 0.289 & 0.289 & 0.288 \\
\hline & $\mathrm{K}$ & 0.701 & 0.722 & 0.738 & 0.750 & 0.759 & 0.784 & 0.794 & 0.799 & 0.802 & 0.805 \\
\hline & $\mu$ & 0.345 & 0.359 & 0.367 & 0.372 & 0.376 & 0.385 & 0.389 & 0.392 & 0.395 & 0.397 \\
\hline $16 R-2,2-5$ & $V_{d}$ & 1.836 & 1.862 & 1.871 & 1.872 & 1.870 & 1.861 & 1.859 & 1.860 & 1.860 & 1.861 \\
\hline \multirow[t]{3}{*}{ Olivine gabbro } & $\sigma^{s}$ & 0.289 & 0.297 & 0.300 & 0.300 & 0.300 & 0.297 & 0.297 & 0.297 & 0.297 & 0.297 \\
\hline & $\mathrm{K}$ & 0.648 & 0.712 & 0.744 & 0.762 & 0.771 & 0.788 & 0.798 & 0.805 & 0.811 & 0.816 \\
\hline & $\mu$ & 0.318 & 0.333 & 0.344 & 0.351 & 0.356 & 0.370 & 0.376 & 0.379 & 0.381 & 0.383 \\
\hline $16 \mathrm{R}-3,42-45$ & $V_{t} / V_{s}$ & 1.766 & 1.790 & 1.800 & 1.806 & 1.810 & 1.819 & 1.824 & 1.827 & 1.787 & 1.832 \\
\hline \multirow{3}{*}{ Olivine gabbro } & & 0.264 & 0.273 & 0.277 & 0.279 & 0.280 & 0.283 & 0.285 & 0.286 & 0.272 & 0.288 \\
\hline & $\mathrm{K}$ & 0.660 & 0.715 & 0.743 & 0.759 & 0.769 & 0.793 & 0.806 & 0.815 & 0.796 & 0.828 \\
\hline & $\mu$ & 0.369 & 0.382 & 0.389 & 0.393 & 0.396 & 0.402 & 0.405 & 0.407 & 0.428 & 0.410 \\
\hline
\end{tabular}

Note: Units for $\sigma$ and $\mu$ are MPa $\times 10^{-2}$

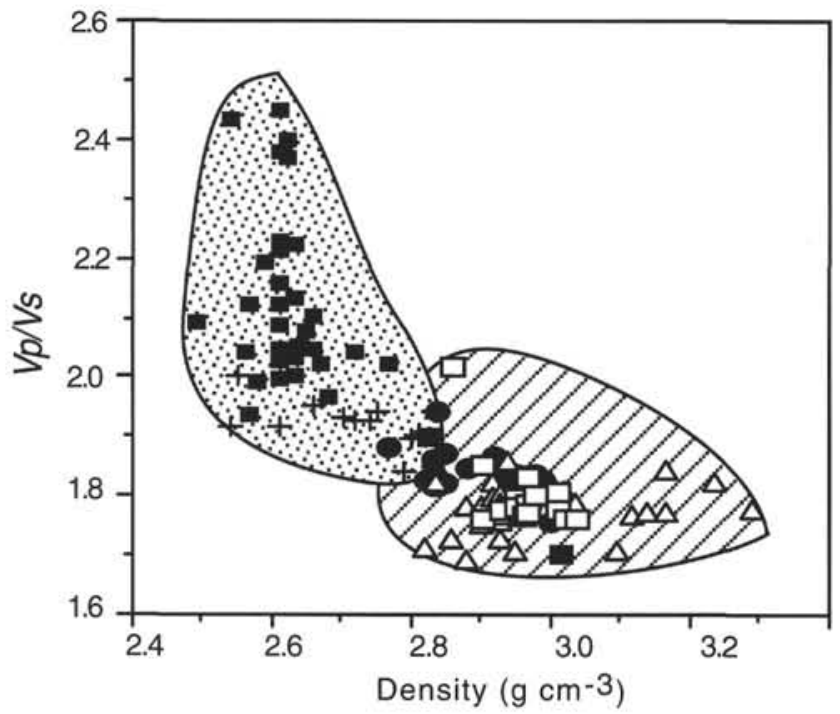

- MARK gabbroic rocks

$\triangle$ SWIR gabbroic rocks

$\square$ Hess Deep gabbroic rocks

- MARK serpentinized peridotites

+ Hess Deep serpentinized peridotites

Figure 12. $V_{p} / V_{s}$ plotted relative to density for gabbroic rocks and serpentinized peridotites sampled at MARK, Hess Deep, and the Southwest Indian Ridge. Data from Hess Deep are from Iturrino et al. (1996). Data from Southwest Indian Ridge are from Iturrino et al. (1991).

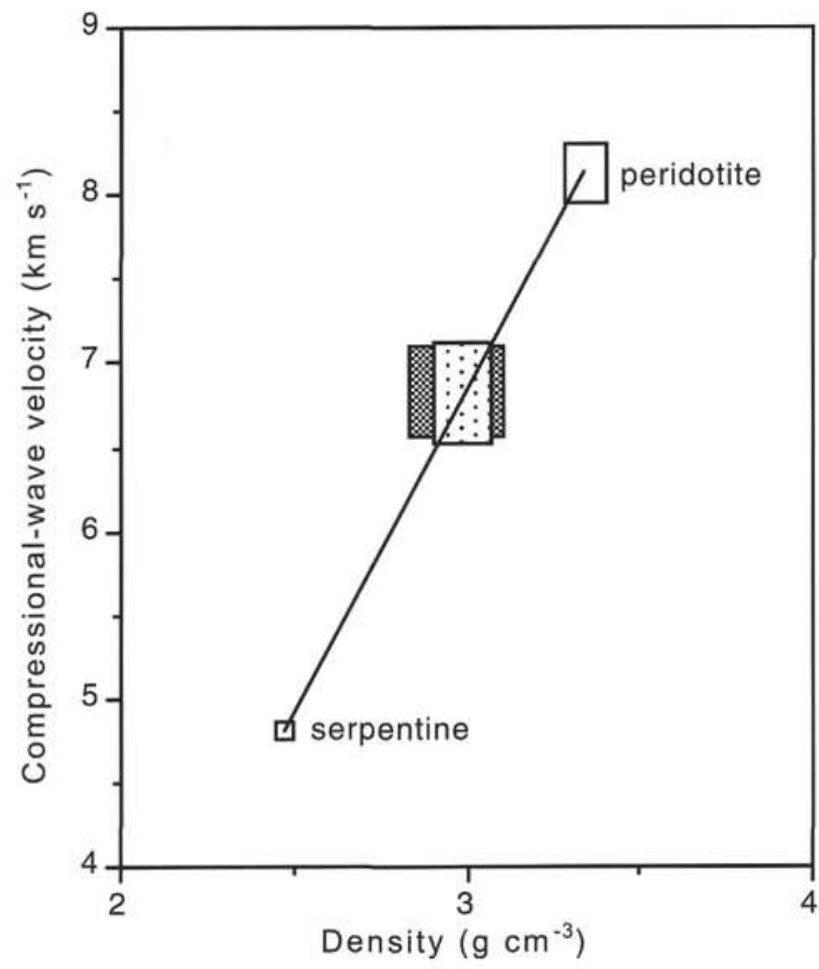

Figure 13. Coincidence of $V_{p}$ and density data for gabbroic rocks and partially serpentinized peridotites. Dark stippled box represents data from gabbroic rocks recovered from Southwest Indian Ridge (Leg 118), Hess Deep (Leg 147), and MARK (Leg 153). Light stippled box represents range of velocity and density values calculated from least-squares regression parameters of worldwide serpentinized peridotites and data from Hess Deep and $\operatorname{MARK}\left(V_{p}=7.95-(2.88 \times\right.$ serpentinized fraction $)$ [R2 $\left.=0.95\right]$; density $=$ $3.30-(0.79 \times$ serpentinized fraction $)[R 2=0.98])$. 


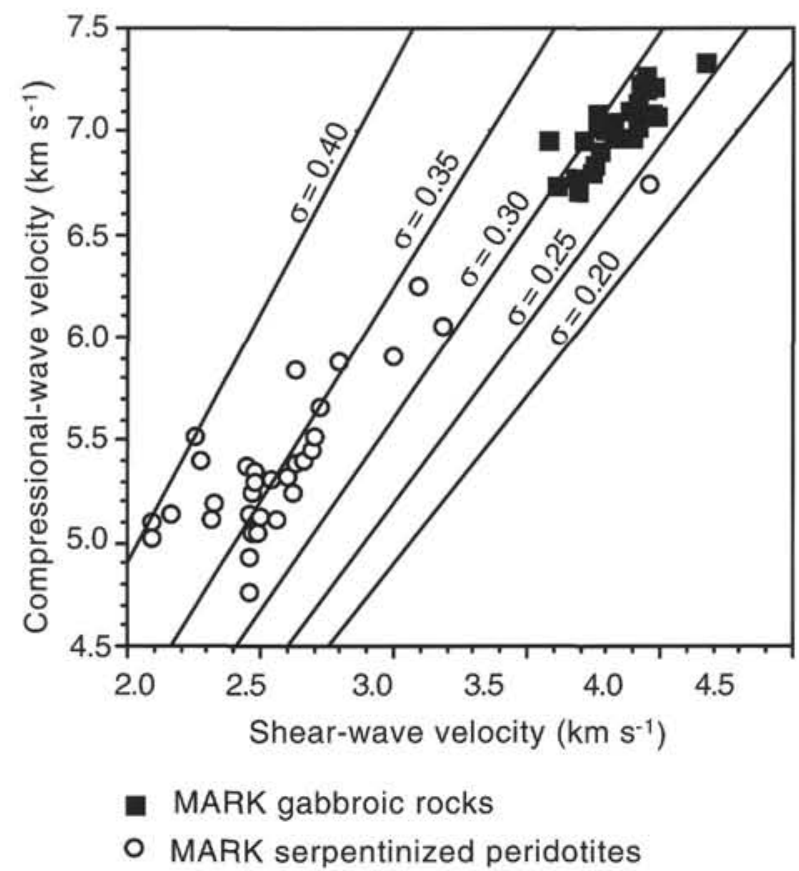

Figure 14. $V_{p}$ plotted relative to $V_{s}$ for all samples analyzed from Leg 153. Also shown are lines of constant Poisson's ratio $(\sigma)$.

Table 7. Comparison of mean elastic constants for gabbroic rocks from MARK (Leg 153), Hess Deep (Leg 147), and Southwest Indian Ridge (Leg 118).

\begin{tabular}{ccccccccc}
\hline & & \multicolumn{8}{c}{$\begin{array}{c}K \\
\text { Leg }\end{array}$} & $V_{p} / V_{s}$ & std. dev. & $\sigma$ & \multicolumn{4}{c}{$\begin{array}{c}\mu \\
\text { std. dev. }\left(\mathrm{MPa} \times 10^{-2}\right)\end{array}$} & std. dev. \\
$\left(\mathrm{MPa} \times 10^{-2}\right)$ & std. dev. \\
\hline 153 & 1.827 & 0.036 & 0.286 & 0.012 & 0.859 & 0.049 & 0.430 & 0.036 \\
147 & 1.800 & 0.061 & 0.275 & 0.018 & 0.807 & 0.040 & 0.427 & 0.046 \\
118 & 1.779 & 0.040 & 0.268 & 0.016 & 0.806 & 0.052 & 0.440 & 0.028 \\
\hline
\end{tabular}

